\title{
Future Lending Income and Security Value*
}

\author{
Melissa Porras Prado
}

\begin{abstract}
I test the Duffie, Gârleanu, and Pedersen (2002) hypothesis that security prices incorporate expected future securities lending income. To determine whether institutional investors anticipate gains from future lending of securities, I examine their trading behavior around loan fee increases. The evidence suggests that institutions buy shares in response to an increase in lending fees and that this could explain the premium associated with high lending fee stocks. Expected future lending income affects stock prices, although the effect seems to be attenuated by the negative information that arises from short selling.
\end{abstract}

Keywords: Security Lending Income, Institutional Investors

JEL: G12, G14

\footnotetext{
* Correspondence: Nova School of Business and Economics, Attn. Melissa Porras Prado. Campus de Campolide, 1099032 Lisboa - Portugal. Email is melissa.prado@novasbe.pt. I thank Hendrik Bessembinder, and an anonymous referee for helping improve this paper. Special words of gratitude also for Miguel Ferreira, for all his guidance and help. I would also like to thank Dion Bongaerts, Dirk Brounen, Richard Evans, Bruce Grundy, Hao Jiang, David Ling, Nimalendran Mahendrarajah, Andy Naranjo, Husza'R Zsuzsa Reka, Jay Ritter, Pedro Saffi, Pedro Santa Clara, Elvira Sojli, Marta Szymanowska, Mathijs van Dijk, Manuel Vasconcelos and Marno Verbeek for comments on earlier drafts. I also thank seminar participants at the University of Florida, Stockholm School of Economics, Universidade Católica Portuguesa, the 11th SAET conference, the 9th EUROFIDAI International Finance Meeting, 12th Symposium on Finance KIT, and Robeco Asset Management. I am grateful to Data Explorers Limited for providing the data and Inessa Love for making available her PVAR routines. This paper was previously circulated as "The Price of Prospective Lending: Evidence from the Security Lending Market" and "The Price of Prospective Lending: Evidence from Short Sale Constraints".
} 


\section{Introduction}

The securities lending market has grown dramatically in the past decade. In July 2008, the New York Stock Exchange reported of a peak short interest of 18.6 million shares, equal to $4.7 \%$ of total shares outstanding. In that same year, the balance of securities on loan in the U.S. grew to $\$ 685$ billion, according to Data Explorers' securities lending yearbook.

Figure 1 plots the average equal-and value-weighted annualized loan fees and loan quantities for stocks from June 2006 through December 2008. Average loan spreads widened from an average of 20-30 basis points (bp) (80 bp equally weighted) in 2006, to over 100 (350 equally weighted) at the height of the 2008 crises. ${ }^{1}$ The number of shares borrowed relative to shares outstanding reached a maximum of $3.1 \%$ in 2008 (5.4\% on an equally weighted basis).

The business of securities lending became lucrative business for funds with large portfolios of stocks. Dimensional Fund Advisors, for example, earned \$182 million in net lending revenue for fiscal year 2008. According to Data Explorers Ltd, U.S. investment companies earned almost $\$ 1.5$ billion overall in 2008 from lending securities.

When they lend shares to short sellers, institutional investors benefit by receiving lending income. I examine whether security prices incorporate this future expected

\footnotetext{
${ }^{1}$ Securities lending involves the temporary transfer of securities by a lender to a borrower. The borrower is required to provide collateral to the securities lender in the form of cash or other securities. Legal title passes on both sides of the transaction so that borrowed securities and collateral can be sold or re-lent. Borrowers are typically required to post collateral of 102 to 105 cents per dollar of security, beyond the $50 \%$ margin when the lender is a U.S. broker-dealer; see D'Avolio (2002) for more details. Loan income can be economically significant. Lending returns are comprised of the securities lending (fee) return and the reinvestment on the cash collateral. If the borrower provides securities as collateral to the lender, he pays a fee to borrow the securities. If the borrower provides cash as collateral, the lender pays interest to the borrower (the rebate rate) and reinvests the cash at the current short-term interest rate. The fee is then the difference between the short-term rate and the rebate rate, expressed in basis points per year. Note the growth in the security lending market was much less in 2012-2013.
} 
lending income. Duffie, Gârleanu, and Pedersen (2002) predict that investors are willing to pay more than their valuation of the share, if they expect to profit from lending in the future when the opportunity arises. The stock price will reflect the expected future income associated with the potential of lending the asset. The prospect of lending fees increases prices beyond even the most optimistic buyer's valuation of the security's future dividends.

Yet, the fact that there is excess demand for shorting can imply that there is negative information that is not yet incorporated into prices. Diamond and Verrecchia (1987) argue that, given that sale proceeds cannot be reinvested, and the additional cost of borrowing securities to short, short sellers are likely to be informed investors. Empirical tests corroborate the information content of shorts as future returns are predictably low when short sale volume is high. ${ }^{2}$ Christophe, Ferri, and Angel (2004), Christophe, Ferri, and Hsieh (2010), Karpoff and Lou (2010), and Boehmer, Jones, and Zhang (2011) find direct evidence that short sellers actually anticipate earnings surprises, financial misconduct, and analyst downgrades. Anticipated lending income means that the same signal that exerts upward pressure on price, also exerts downward pressure, due to the implied negative information. The outcome of these two competing effects is an empirical question. I address whether institutional investors anticipate lending income and are willing to pay a premium for stocks in which they expect high lending fees.

Both the theoretical and empirical literature agree that short selling frictions have important implications for asset prices. At the same time, there is no consensus as to the source of price inflation associated with short sale constraints, such as the presence of a high borrowing fee. Disagreement models like Miller (1977) attribute price inflation

\footnotetext{
${ }^{2}$ Brent, Morse, and Stice (1990); Senchank and Starks (1993); Aitkan, Frino, McCorry, and Swan (1998); Dechow, Hutton, Meulbroek, and Sloan (2001); D'Avolio (2002); Desai, Ramesh, Thiagarajan, and Balachandran (2002); Geczy, Musto and Reed (2002); Jones and Lamont (2002); Angel, Christophe and Ferri (2003); Lamont (2004); Asquith, Pathak, and Ritter (2005); Boehme, Danielsen, and Sorescu (2006); Boehmer, Jones, and Zhang (2008); Diether, Werner, and Lee (2009); and Boehmer, Huszár, and Jordan (2009) show that short sales predict abnormally low future returns.
} 
to the optimism of the marginal investors. Any restriction would lead the price to be set by the most optimistic buyers, as short sales, in the presence of divergence of opinions effectively increase the supply of shares, thereby correcting the exuberant but downward-sloping demand.

In static models, the price is as high as the valuation of the most optimistic investors (e.g., Miller (1977), and Chen, Hong, and Stein (2002)). In a dynamic setting, short sale constraints can cause prices to be higher than the valuation of all investors. In Harrison and Kreps' model (1978), differences of opinion, together with short sale constraints, create a speculative premium. ${ }^{3}$

Duffie, Gârleanu, and Pedersen (2002) present a dynamic model of asset valuation in which short selling requires searching for security lenders and bargaining over the lending fee. Search frictions allow for lender expropriation, and the expectation of lending fees, in turn, increases the equilibrium price. This suggests that price inflation could represent a capitalization of future lending income. In the Treasury repo market, Duffie (1996) shows that special repo rates increase the equilibrium price of the underlying instrument. Duffie, Gârleanu, and Pedersen (2002) extend the theoretical relation to equity and fixed-income security lending. This paper builds on the theoretical research of Duffie, Gârleanu, and Pedersen (2002) by investigating empirically whether security prices in the equity market incorporate prospective security lending income.

In this paper, several empirical findings suggest that institutions respond to increases in lending fees and that their trading behavior contributes to the overvaluation of high fee stocks. In a univariate analysis, I observe an increase in institutional ownership and number of institutions investing in a stock two quarters before and after it becomes expensive to borrow. The average inventory levels in these stocks increases two quarters before the fee reaches the threshold level, and this trend continues in the following

\footnotetext{
${ }^{3}$ According to Scheinkman and Xiong (2003) and Hong, Scheinkman, and Xiong (2006) this speculative premium leads to high turnover, overpricing, and even to bubbles.
} 
quarters. There is no such similar trend in the stocks that are not expensive to borrow. I also observe an increase in the number of stocks on loan in the quarters following the high fee, suggesting that the increased inventory translates in part into loans. Moreover, the actual fee on high fee stocks decreases sharply, in accordance with an increase in supply.

Impulse-response functions following a panel VAR show that a one standard deviation increase in the lending fee increases institutional ownership by $0.50 \%$ and the number of institutions holding the stock by $0.90 \%$ in the following quarter.

I find that institutions tend to buy shares in response to an increase in lending fee. An observed increase in lending fee for a stock makes institutions 1.33 times more likely to buy. Institutions also respond to the predictable component in lending fees, suggesting they actually anticipate lending income.

I also examine the security lending practices of mutual funds in particular and find the aggregate lending income to be an important predictor of whether a mutual fund will allow security lending. Mutual funds are also two times more likely to increase their holdings in a stock if the stock has experienced an increase in lending fee, suggesting that mutual funds could be buying high fee stocks for the purpose of lending.

Most importantly, the overvaluation associated with high lending fees is most pronounced among stocks that institutional investors are trading in the direction of the high fee possibly to gain lending income. For example, among stocks with intense institutional trading, the contemporaneous average four-factor alpha spread between high and low fee stocks is $2.78 \%$ per month (t-statistic $=3.52$ ). Among stocks with low institutional trading, the contemporaneous risk-adjusted return spread between high and low fee stocks is actually negative and statistically significant. When including firm level controls in a Fama-Macbeth specification the contemporaneous difference in risk-adjusted return between a top fee quintile stock that is bought by institutional investors and a high fee 
stock that is not bought by institutions is $2.64 \%$ per year. This suggests that institutional investors tend to trade in the direction of high expected lending income and that those trades contribute to the premium on high fee stocks. These results are consistent with a view that institutional investors are willing to pay a premium for high fee stocks and that future lending income is capitalized into prices.

I also find that institutions are less willing to purchase shares that experienced both an increase in borrowing cost and negative earnings news. The results seem to suggest that there is a trade-off between lending income and the implied negative information from short selling. Moreover, the premium for high fee stocks is insignificant in the subsample of stocks that experience a negative information shock.

These findings combined are consistent with institutional investors realizing the advantages of security lending and that the expectation of lending income contributes to some of the overvaluation of high fee stocks.

My results have important implications for the literature on equity lending. The balancing out of the two forces, capitalized lending income and the negative information inherent in short selling, could explain why Kaplan, Moskowitz, and Sensoy (2012) find that although making securities available for lending is profitable, it does not affect the price of the underlying securities. The capitalization of lending income can also explain the pricing differences among various measures of short sale constraints. Lending income could explain Boehmer, Huszár, and Jordan's (2009) finding that stocks with low short interest experience positive abnormal returns, given that D'Avolio (2002) shows that the mean loan fee is also high in the first short interest portfolio decile. Especially when considering that for the low short interest decile there is high potential for lending in the future. Similarly, the capitalization of lending income can explain the finding of Autore, Boulton, and Braga-Alves (2010) that stocks reaching threshold levels of failures with low short interest become more overvalued than threshold stocks with high short 
interest. My results show that institutional investors seem to respond to an increase in expected lending income, when the expectation is formed using signals from publicly available failure-to-deliver data.

This work contributes to the literature on short sale constraints and valuation. Seneca (1967), Miller (1977), Harrison and Kreps (1978), Figlewski (1981), and Morris (1996), among others, argue that security prices are upward biased when there are short sale constraints because negative information is not fully incorporated into prices. My results suggest that short selling constraints can cause prices to deviate from the intrinsic value due to the capitalization of future lending income. The tendency of institutional investors to trade in the direction of high expected lending income exacerbates the price overreaction, thereby contributing to the premium on high fee stocks. To the best of my knowledge, I am the first to show empirically that future lending expectation affects current stock prices and that the extent of this effect arises from a trade-off between negative information and security lending income.

The paper is organized as follows. Section II describes the data and the summary statistics. Section III reports the univariate results on the response of institutional investors to an increase in lending fee and Section IV the multivariate analysis. In Section V, I test whether institutional investors are willing to pay a premium for high fee stocks. Section VI documents a trade-off between lending income and the implied negative information from short selling. Section VII examines the security lending and portfolio decision of mutual funds. Section VIII includes a robustness check of the results, and Section IX concludes. 


\section{Data}

The data for this study come from various sources. I obtain quarterly institutional holdings for all common stocks from the Thomson Reuters CDA/Spectrum database of Securities and Exchange Commission 13F filings. Institutional ownership for each stock is defined as the number of shares held by institutional investors divided by the total number of shares outstanding. ${ }^{4}$ I exclude observations with total institutional ownership greater than $100 \%$. Stock return, share price, number of shares outstanding, and turnover data come from the Center for Research in Security Prices (CRSP) for all NYSE/AMEX/NASDAQ stocks and the book value of equity and dividends from COMPUSTAT. S\&P500 constituent data is from the COMPUSTAT annual updates index constituents. The information on earnings and surprises comes from the unadjusted surprise history file in $\mathrm{I} / \mathrm{B} / \mathrm{E} / \mathrm{S}$.

The security lending data are from Data Explorers Ltd., which collects data from custodians and prime brokers that lend and borrow securities. The data include daily stock-level information on the loan fee, the borrowed amount, and the dollar value and quantity of shares available for lending. This covers the equity lending supply, loan prices, and quantities for 4,393 U.S. firms from June 2006 through December 2008. While the sample period is short, it does coincide with the two years when security lending activity and income reached their highest levels. I supplement the loan data with short interest data from Short Squeeze and with failure-to-deliver records from the SEC. Failure-to-deliver data include the total number of fails-to-deliver (i.e., the balance level outstanding) recorded in the National Securities Clearing Corporation's (NSCC) Continuous Net Settlement (CNS) system aggregated over all NSCC members. ${ }^{5}$

\footnotetext{
${ }^{4}$ This represents the long institutional ownership, not net institutional ownership of a stock.

${ }^{5}$ Available at http://www.sec.gov/foia/docs/failsdata.htm, Data prior to September 16, 2008, include only securities with a balance of total fails-to-deliver of at least 10,000 shares as of a particular settlement date. Data after that date include all securities with a balance of total fails-to-deliver as of a particular settlement date.
} 
My main tests use quarterly and monthly data. For the quarterly institutional ownership trading tests, because institutional ownership data are reported quarterly, I compute quarterly averages of equity lending variables for each stock. Since I calculate the change in fee, I lose the third quarter of 2006. The final merged sample covers 30,642 firm-quarter observations for 4,040 stocks. In the second set of tests, I examine whether the monthly overvaluation associated with the presence of high fees is more pronounced among stocks that institutions are trading in the direction of the increasing borrowing cost. There are again 4,040 stocks in the sample for a total of 66,011 firmmonth observations.

Table 1 shows summary statistics. Panel A reports the number of observations (N), means, medians, standard deviations (Stdev), and quartile distributions $(25 \%, 75 \%$ ) of the variables. The average institutional ownership $(I O)$ in the sample of common equity stocks is $54.24 \%$, representing 140 institutional investors, on average (NIO). The average annualized fee $(F e e)$ over the sample period is $0.99 \%$. The loan fee increased for about $35 \%$ of the stocks, although the average change in fee is a reduction of 1 basis point. On average $4.20 \%$ of the shares outstanding are borrowed (On Loan), and the average short interest $(S I R)$ is $4.07 \%$.

Panel $\mathrm{B}$ reports the differences between the stocks with fees below and above 1\%, a threshold used by D'Avolio (2002) and Prado, Saffi, and Sigurdson (2012) to classify stocks as on special. The stocks with high fees (above 1\%) differ significantly from the low fee stocks. Most notably, the average institutional ownership of the top fee quintile is significantly lower than that of the low fee stocks, $36.81 \%$ versus $62.76 \%$. This is in line with D'Avolio (2002) and Nagel (2005), who show that stock loan supply tends to be scarce and short selling more expensive when institutional ownership is low. The average annual fee is $4.26 \%$ for the top fee stocks, a number similar to D'Avolio (2002) who documents a value-weighted average fee of $4.30 \%$ for stocks on special. Moreover, 
stocks in the high fee group are shorted more, have lower inventory, both in number of accounts and in levels (and therefore also higher utilization rates), are smaller, have higher turnover, are more volatile, and have lower returns.

\section{Univariate Results}

In Figure 2, I use the same 1\% threshold of when a stock becomes expensive to borrow of D'Avolio (2002) and Prado, Saffi, and Sigurdson (2012), and examine the percentage change in institutional ownership two quarters before and after a stock reaches the threshold level. ${ }^{6}$ The top two panels show the percentage change of institutional ownership for stocks with short selling fees above 1\% (left) and the below 1\% (right) two quarters before and two quarters after classification at time $t$. Institutions are increasing their positions in both high and low fee stocks prior to time $t$, but this effect is much larger for the high fee stocks. Interestingly, in the high fee stocks institutions continue to increase their holdings in these high fee stocks in the quarters following the stock becoming special. Institutional ownership increases $7.4 \%$ in the two quarters after reaching the fee level 1\%, from 36.81 to 39.57 percentage points. This increase pertains only to the high fee stocks, as there is no increase in institutional ownership in the remaining stocks (right). In fact, there appears to be a decline of $3.5 \%$ in institutional ownership in the following 2 quarters in stocks whose fees are not above $1 \%$ at time $t^{7}$ A similar trend is visible in the number of institutional investors holding each stock. The bottom two panels in Figure 2 show the percentage change in the number of institutional investors holding stocks with lending fees above 1\% (left) and stocks with fees below that level (right) two quarters before and two quarters after classification at time t. The number of institutions holding the high fee stocks increases from 59, on average

\footnotetext{
${ }^{6} \mathrm{~A}$ similar pattern arises when looking at the top quintile of fee stocks.

${ }^{7}$ In unreported results the average institutional ownership change around high fees is significantly higher for stocks held mostly by funds that allow security lending versus stocks held mostly by mutual funds that are not allowed to lend.
} 
at time $t$, to 64 and 70 in the next two quarters, an increase of $18.6 \%$. In the low fee stocks, the average number of institutions investing in those shares actually drops $6.7 \%$ from 179 to 167 in the following two quarters. This univariate analysis suggests that a high fee sparks the interest of institutional investors.

To determine whether institutional investors are buying the high fee stocks for the purpose of lending to short sellers, I examine the change in average fee, the inventory, loan quantities, and utilization of stocks two quarters before and after a stock reaches the threshold level of fees of $1 \%$ in Figure 3. For stocks that are expensive to borrow, the average fee (top left graph) decreases by 190 and 49 basis points following a peak at time $t$ in the following two quarters, a finding consistent with the idea that institutional ownership translates into an increase in supply which in turn decreases the loan fee. In effect, the average inventory levels relative to shares outstanding (top right graph) already start to increase two quarters before the fee reaches the threshold level, and this trend continues in the following quarters. There is no such similar trend in the stocks that are not expensive to borrow. I also observe an increase in the number of stocks on loan in the quarters following the high fee (bottom left graph). Although the increase is not that large relative to shares outstanding, it suggests that the increased inventory translates in part into loans. Moreover, I do not observe an increase in loan quantities for the stocks with lower lending fees. In terms of utilization (bottom right graph), the value of assets on loan relative to the lendable asset value, the increased inventory leads to a reduction in utilization and the increased loan quantities to an increase, so the net effect is no significant change in utilization for the high fee stocks. 


\section{Institutional Trading in Response to an Increase in Lending Fee}

In this section I test whether an increase in borrowing charges triggers the interest of institutional investors, by examining how an increase in lending fee influences changes in institutional holdings. To explain the joint relation of institutional ownership and the loan fee, I use a first-order panel vector autoregression approach (PVAR). ${ }^{8}$ This is a multivariate simultaneous equation system that treats all variables as endogenous, while allowing for unobserved stock heterogeneity, using the Blundell and Bond (1998) system GMM dynamic panel instrumental-variables (IV) estimation. ${ }^{9}$ The estimator relies on first-differences to eliminate unobserved stock-specific effects and then uses lagged levels and difference values of the endogenous variables as instruments for subsequent firstdifferences. ${ }^{10}$

First, to capture institutional ownership trading as a function of the fee, I specify a first-order VAR model as follows: ${ }^{11}$

$$
y_{i, t}=\Upsilon_{0}+\Upsilon_{1} y_{i, t-1}+f_{i}+d_{t}+\epsilon_{i, t}
$$

where $y_{i, t}$ is a vector including the change in institutional ownership $(\Delta I O)$, and the annualized lending fee in Panel A. In Panel B, I include the quarterly stock return to control for changes in stock price, which might lead to changes in short sellers' demand and in turn lending fees and institutional ownership. $f_{i}$ introduces stock fixed effects and $d_{t}$ period-specific time dummies. In Panel $\mathrm{C}$ and $\mathrm{D}$, the $y_{i, t}$ vector includes changes

\footnotetext{
${ }^{8}$ The estimation is implemented using a PVAR routine by Inessa Love. See Love and Zicchino (2006) for computational details.

${ }^{9}$ The Blundell and Bond (1998) system GMM, outlined by Arellano and Bover (1995) and fully developed by Blundell and Bond (1998), is an augmented version of the Arellano-Bond (1991) estimator.

${ }^{10}$ First differences are used as instruments in the levels equation, lagged levels are used to instrument in the first difference equation.

${ }^{11}$ The lag length was selected following the AIC.
} 
in the natural $\log$ of one plus the number of institutional investors $(\Delta \ln (1+N I O))$. Panel $\mathrm{C}$ is the two-variable panel VAR, while Panel D includes the stock return. The results are in Table $2 .{ }^{12}$

There is a positive relation between the lagged annualized fee and changes in institutional ownership (Panel A). An increase in institutional ownership in turn reduces the lending fee. The results are even stronger when controlling for lagged stock returns (Panel B). An increase in the fee leads to an increase in the number of institutions holding the stocks (Panel C and D).

The impulse-response functions in Figure 4 further describe the reaction of institutional investor ownership changes to the innovations in the lending fee, while holding all other shocks at zero. A one standard deviation shock in the fee increases institutional investor ownership by $0.50 \%$ (top right graph) in the following quarter. Consistent with findings of Prado, Saffi, and Sturgess (2012), the fee in itself drops significantly with an increase in institutional ownership as the supply of shares increases (top left graph). The bottom graphs show the reaction of the change in the number of institutions holding the stock to a one standard deviation shock to the fee (bottom right graph) and the reaction of the fee to a one standard deviation shock to the change in the number of institutional holdings (bottom left graph). A one standard deviation increase in the fee increases the number of institutional investors by $0.90 \%$ in the following quarter. A standard deviation increase in the number of institutions in turn reduces the lending fee by 8 basis points. The results are similar when I use a dummy variable to indicate the presence of a high fee in the previous quarter or an increase in lending fee. Figure 1 in the appendix shows the impulse response graphs for the reaction of both institutional ownership changes and the change in the number of institutions to the presence of a

\footnotetext{
${ }^{12}$ The particular ordering of the specification is important. The variables that appear earlier in the system are assumed to be more exogenous while the later ones are assumed to be more endogenous. Nonetheless, the results are robust to changes in the order.
} 
high fee or fee increase.

Next I examine how an increase in lending fee influences institutional trading in a fixed effects panel regression. The specification is:

$$
\begin{aligned}
& \text { Trading }_{i, t}=\alpha_{i}+\alpha_{t}+\beta_{1} \text { Fee increase }_{i, t}+\beta_{2} \ln (\text { Mcap })_{i, t}+\beta_{3} \text { Bid }- \text { Ask }_{i, t} \\
& +\beta_{4} \text { Turnover }_{i, t}+\beta_{5} \text { Price }_{i, t}+\beta_{6} S \& P 500_{i, t}+\beta_{7} \text { Age }_{i, t} \\
& +\beta_{8} \text { Stdev }_{i, t}+\beta_{9} \text { Ret }_{i, t-1}+\beta_{10} M T B_{i, t}+\beta_{11} \text { Dividend }_{i, t}+\epsilon_{i, t}
\end{aligned}
$$

where the dependent variable is the change in institutional ownership $(\Delta I O)$ or changes in the natural log of one plus the number of institutional investors $(\Delta \ln (1+N I O))$ in stock $i$ at time $t$. I also run the specification with the dependent variable in levels, $I O_{i, t}$, the level of institutional ownership in stock $i$ at time $t$ and the natural log of 1 plus the number of institutional investors, $\ln (1+\mathrm{NIO})$. Fee increase $_{i, t}$ is a dummy variable that equals one if the average quarterly lending fee on the stock has increased over the previous quarter. Following Gompers and Metrick (2001) and Yan and Zhang (2009), I include the stock characteristics firm size (Mcap) (the natural log of equity market capitalization), past quarterly return $\left(\operatorname{Ret}_{i, t-1}\right)$, Price, Age, S\&P index inclusion $\left(S \& P 500_{i, t}\right)$, and volatility $\left(\operatorname{Stdev}_{i, t}\right)$ to control for the common determinants of institutional holdings. To control for liquidity and transaction costs, I include the bid-ask spread $\left(\right.$ Bid $\left.-A s k_{i, t}\right)$ and Turnover, which also accounts for differences in opinions as in Boehme, Danielsen, and Sorescu (2006). ${ }^{13}$ I include market-to-book value (MTB) as research by Jiang (2009) shows that institutions trade in the direction of intangible information inherent in the book-to-market ratio. Dividend $_{i, t}$ is an indicator variable that equals one if the stock pays a dividend as reported in Compustat. Finally, to control for the visibility of stocks I include NumAnalyst, which is the number of analysts following the stock, as reported in the unadjusted surprise history file in I/B/E/S, where missing

\footnotetext{
${ }^{13}$ The results are robust to the inclusion of analyst dispersion, but this limits the sample size to only the largest stocks.
} 
values are set to zero. The regression includes year and stock fixed effects. Robust standard errors are clustered by stock to account for within-firm serial correlation. Lastly, I examine whether institutional investors buy a stock in a fixed effects logit specification with the same control variables $\left(\right.$ Controls $\left._{i, t}\right)$, where a buy $\left(\right.$ buy $\left._{i, t}\right)$ is a dummy variable equal to one when institutional investors increase their holdings in the stock.

$$
\begin{aligned}
& \left.\operatorname{Prob}_{\text {buy }_{i, t}=1 \mid \text { Fee }_{\text {increase }}, t}, \text { Controls }_{i, t}, \alpha_{i}, \alpha_{t}\right)=
\end{aligned}
$$

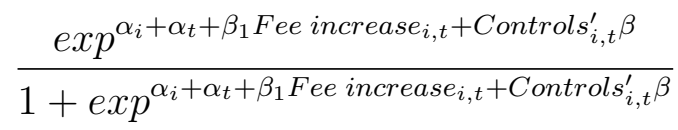

where $\alpha_{i}$ introduces stock fixed effects and $\alpha_{t}$ period-specific time dummies.

The first two columns in Table 3 the dependent variable is the level of institutional ownership and the log of one plus the number of institutional investors. Column 1, show that in line with Yan and Zhang (2009) institutions prefer to hold larger stocks, stocks with higher turnover, and stocks with lower MTB ratios. Consistent with the findings in Gompers and Metrick (2001), the coefficient on past return is significantly negative. Institutions also prefer dividend-paying stocks, as the coefficient of the dividend-paying dummy is positive and significant.

Column 2 shows that larger, higher priced stocks, dividend paying stocks, and stocks that are younger and more volatile are held by a higher number of institutional investors. Institutions also seem to prefer stocks that have seen lending fees rise. As we see in the table, stocks with increases in borrowing costs have a $0.98 \%$ higher institutional ownership (column 1), and 1.89\% more institutions hold the stock (column 2), in terms of levels. Columns 3-5 describe the trading behavior of institutional investors. Institutions tend to trade larger and less volatile stocks, which have seen their returns decrease. More important, an increase in lending fees is associated with an increase of $0.89 \%$ in institutional ownership and $1.40 \%$ more institutions holding the stock. Column 5, reports the odds following the panel logit regression of the likelihood of buying a stock. 
Stocks that experience an increase in lending fees are 1.33 times more likely to be bought by institutional investors.

\section{A The Expected Future Lending Income}

To determine whether institutional investors anticipate lending income and trade in the direction of high expected lending fees, I first predict an increase in lending fee as a function of publicly available information and stock characteristics and study the relation between expected lending income and institutional ownership. A second prediction includes proprietary information on inventory and loan values as reported by Data Explorers, which more institutions are starting to subscribe to.

An important determinant of short sale fees is the frequency of so-called failure-todeliver occurrences within a quarter. At the time a short position is initiated, the short seller has three days to locate and borrow the shares from a securities lender. Short sellers that have not located shares from owners by that time are said to have failedto-deliver; see Evans, Geczy, Musto, and Reed (2009) for details. According to Blocher, Reed, and Van Wesep (2012) the failure-to-deliver list attracts investors' attention and signals an increased likelihood that stocks may be becoming special. I use the failureto-deliver data to test whether an increase in expected borrowing fees would trigger the interest of institutional investors and prompt their increased ownership. The advantage of using the cumulative occurrence of a failure to determine whether security lenders discount expected lending income in their valuation is that it is public information. ${ }^{14}$

In the second prediction I add utilization, which is the value of assets on loan from beneficial owners (beneficial owner value on loan) relative to the total lendable asset value (beneficial owner inventory value) from Data Explorers. In both predictions I also include common short sale determinants. Dechow, Hutton, Meulbroek, and Sloan (2001)

\footnotetext{
${ }^{14}$ The results are robust to exclusion of the failure occurrence variable.
} 
show that short sellers position themselves in stocks with low ratios of fundamentals to market values, so as before I include the market-to-book (MTB) ratio. I include the standard deviation of returns and turnover, similar to Boehme, Danielsen, and Sorescu (2006), as a measure of divergence of opinion, as the heterogeneity of beliefs about a firms fundamentals is expected to be related to the degree of short selling (Miller, 1977). Diether, Lee, and Werner (2008) show that short sellers position themselves in stocks with positive returns, and therefore I include past quarterly return. Additional costs to short sellers are dividend payments, because stock prices tend to fall by less than the amount of the dividend the short seller is required to reimburse, which could lead to a lower lending fee. I therefore include an indicator of whether the stock pays dividends. Other stock characteristics included are size, age, S\&P 500 indicator, bid-ask spread, and the price level.

In Table 4, the first two columns in the left-hand panel show the predictive regressions, and columns 1-6 in the right-hand panel are the panel regressions of institutional trading on the predicted fee. The two stages are estimated simultaneously to adjust the standard errors in the second stage for the estimation error in the first stage.

The first columns in Table 4 show that failure-to-deliver is an important determinant of the actual lending fee. A failure-to-deliver increases the likelihood of a fee increase. ${ }^{15}$ An increase in predicted fee leads to a much stronger response in institutional ownership than the actual fee change (column 1, right panel). An increase in expected lending fee increases institutional ownership of stocks by $5.95 \%$ and numbers of institutions increase by $11.58 \%$. Institutional investors are 1.24 times more likely to buy shares of stocks whose lending fee they expect to increase. Institutional investors respond more to the expected fee than an actual fee increase, suggesting that they buy stocks in anticipation of lending income in the future when the opportunity to lend arises. Institutional investors respond slightly less to the predicted fee when we include proprietary informa-

\footnotetext{
${ }^{15}$ The results are similar when predicting the actual fee level.
} 
tion in the prediction regression (column 2), but the response is still greater than to the actual fee increase.

\section{The Price of Prospective Lending}

Next I test whether the overvaluation associated with high fees is more pronounced among stocks that institutions are trading. I perform a monthly Fama-MacBeth (1973) analysis and a two-way $(5 \times 5)$ independent portfolio sort of institutional trading and lending fee to test whether there is a higher premium on high fee stocks, measured as the difference in returns between high and low fee stocks, in stocks with high levels of institutional trading.

First, in Figure 5, I rank stocks into five groups on the basis of the amount of trading (i.e. change in institutional ownership in each quarter) and calculate for each group the average change in fee in basis points. As we see in the top graph, the stocks

with the highest increase in institutional ownership also have on average increasing lending fees, while the sold stocks have seen lending fee declines. The bottom graph clearly distinguishes the direction of the trade, with the sample partitioned into buy or sell, an increase or decline in institutional ownership, respectively. The figure shows that institutions tend to sell stocks with declining lending fees and buy stocks with increasing lending fees.

In Table 5 I perform a portfolio analysis, sorting each stock into fee and institutional trading quintiles. The first two quintiles represent an average decrease in ownership and as of quintile 3 the average change is an increase in holdings, which is increasing in quintiles 4 and 5. The premium on high fee stocks, the difference in returns between high and low fee stocks, is positive and significant only for stocks that are highly bought by institutional investors. On a raw return basis, the top fee and institutional trading 
quintile has a positive return of $1.08 \%$. The difference in contemporaneous raw returns between the high fee stocks in the highest institutional trading quintile and the lowest fee stocks is $2.23 \%$. This difference cannot be explained by one-factor, or four-factor model so the risk-adjusted premium on the high fee stocks is more than $2.75 \%$ per month. The premium difference between high and low fee stocks that are bought by institutional investors versus the ones that are sold is $5.99 \%$. These results are consistent with the premise that institutional investors trade in the direction of high fees to gain lending income, thereby contributing to the overvaluation of high fee stocks.

I also perform a Fama-MacBeth (1973) analysis that allows for the inclusion of additional stock level controls. I control for size, market-to-book, liquidity as measured by bid-ask spread and turnover, the number of analysts following the stock and two dummy variables that equal one when a stock pays a dividend or is in the S\&P 500 index. I classify stocks as Special if they are in the top $20 \%$ of the fee distribution. I interact this indicator variable with another indicator variable that equals one if institutional investors purchase the stock, to test whether the high premium on high fee stocks versus low fee stocks is higher when the stocks are acquired by institutional investors.

As can be seen from the results in Table 6, column 1, a stock in the top fee quintile does not trade at a premium in itself, as indicated by a negative coefficient on the indicator variable special. The positive and statistically significant interaction term of the Special and $_{\text {Buy }}$ shows that the overvaluation is present solely for stocks that are bought by institutional investors. The difference in risk-adjusted return between a stock that is bought by institutional investors and is in the top $20 \%$ of the fee distribution and a top fee quintile stock that is not bought by institutions is $2.64 \%(0.22 \times 12)$ per year.

In column 2, I interact the special indicator variable with another indicator variable that equals one if institutional investors purchased the stock in the previous quarter 
$\left(B u y_{t-1}\right)$ to test whether institutional trading behavior contributes to the overvaluation associated with high fees. The univariate and multivariate analyzes show that institutions position themselves into stocks already one quarter before the stock is classified as expensive. Specifically I am interested to see whether stocks that have been bought by institutions in the previous quarter, to possibly gain lending income, subsequently trade at a premium when the stock becomes expensive to borrow. Moreover, by lagging the institutional ownership trade variable I avoid the contemporaneous price impact associated with the purchase of the share by the institution. The difference in risk-adjusted return between a high-fee stock that was bought by institutional investors in the previous quarter and a top fee quintile stock that was not bought by institutions is $4.32 \%$ $(0.36 \times 12)$ per year.

In column 3, I study the relation between expected lending income and returns. I predict the lending fee as a function of publicly available information (as in the first stage of Table 4) and test whether the premium on high expected fee stocks (the difference in returns between high expected and low expected fee stocks) is positive and significant for stocks that have been bought previously by institutional investors. $\widehat{\text { Specia }}_{t}$ refers now to a stock in the top quintile of the predicted fee distribution. The coefficient on the interaction between high expected fee and institutional buying is positive and significant but smaller economically. Stocks in the top fee quintile that have been bought by institutional investors in the previous quarter experience a 19 basis point increase in monthly abnormal return or $2.28 \%$ per year.

In column 4, the prediction includes proprietary loan information. Here the abnormal return associated with high fee stocks that have been bought by institutional investors, while positive, is not significant.

While institutions seem to respond by increasing their holdings more strongly to an increase in expected lending fee than to the actual fee, the premium they pay is smaller, 
possibly because of the uncertainty associated with the expectation. Nonetheless, the results are consistent with the premise that institutional trading in the direction of the high fee contributes to the overvaluation of high fee stocks.

In Figure 6, I take a closer look at the abnormal returns in the subsequent 6 months using the same portfolio and Fama-Macbeth analyses. The top graph (doted bar) shows the total annualized 4 factor abnormal return of the top fee quintile of stocks following a calendar portfolio approach, up to 6 months after being ranked into the top fee quintile at time $t$. The graph also shows the difference between the premium on high minus low fee stocks for stocks that have been bought by institutional investors in the previous quarter versus stocks where the institutional holdings did not increase (solid bar).

The graph below (doted bar) shows the total annualized 4 factor abnormal return of the top fee quintile of stocks after controlling for stock characteristics like size, MTB, age, standard deviation of returns, S\&P 500 indicator, bid-ask spread, turnover, number of analysts, and whether the stock pays dividends in a Fama-Macbeth regression.

The annualized abnormal returns (dotted bars) are positive at time $t$, but decrease in the following quarters in line with the reduction in short selling constraint leading to a decrease in returns, as in Cohen, Diether, and Malloy (2007). The graph also shows the difference between the premium on high minus low fee stocks for stocks that have been bought by institutional investors in the previous quarter versus stocks where the institutional holdings did not increase (solid bars), the equivalent of the interaction term of special and the increase in institutional ownership indicator variable. As can be seen from the solid bars the premium difference-in-difference is positive and significant at least in the following quarter after the stock is classified as special. 


\section{Negative Information Trade-off}

That stocks with high lending fees trade at a premium to low fee stocks and that that premium is related to institutional trading suggests two results: future lending income is capitalized into prices, and institutions anticipate the lending income and contribute to the overvaluation. This does not mean that the negative information inherent in short selling could not offset this effect.

Disagreement models suggest that excess demand for shorting implies there is negative information that is not yet incorporated into prices. The fact that short sale trades predict future stock returns suggests that short sellers are informed, and could potentially have access to private information.

This means that the same signal that exerts upward pressure on price, because of the lending income, could also exerts downward pressure, because of the implied negative information. The effect of these two competing factors could balance out.

I examine the interplay of information from disagreement predictions by first examining how an increase in lending fee influences the buying behavior of institutional investors in the presence of negative news. I specifically test whether institutions are less willing to purchase stocks that experience an increase in borrowing cost but also have negative earnings news in a panel logit regression. I include two measures of negative news. The first measure is an indicator variable that equals one if the company announces negative earnings (Negative Earnings $s_{i t}$ ), as reported in the unadjusted surprise history file in $\mathrm{I} / \mathrm{B} / \mathrm{E} / \mathrm{S}$. The second is the earnings surprise, the announced earnings in excess of analysts' consensus forecasts. This dummy variable, (Negative Surprise ${ }_{i t}$ ), equals one if the reported earnings are lower than analyst expectations.

I measure the differential response of institutional investors holdings to an increase in fee and a change in fee for stocks with negative news by including an interaction between 
the fee increase $\left(F_{e e}\right.$ increase $\left._{i t}\right)$ or the change in fee $\left(\Delta F e e_{i t}\right)$ and the negative news variable. The results in Table 7 show that both the fee increase dummy and the change in fee increase the likelihood the stock will be bought, but this effect weakens in the presence of negative information. The results suggest that institutional investors realize there is a trade-off between lending income and the implied negative information from short selling, as they are less willing to buy high fee stocks that experience a negative information shock.

Then, I test whether the overvaluation associated with high fee stocks is also less pronounced when stocks experience a negative information shock. I rerun the FamaMacBeth analysis for the subsample of stocks that experience a negative information shock using the same two measures, negative earnings, and negative earnings surprise, in Panel A of Table 8. The coefficient on the interaction of the high fee indicator and whether the stock was bought in the previous quarter by institutions is not significant, neither for the actual fee (columns 1-3), nor the expected fee (columns 4-9). The premium that institutional investors pay for high fee stocks is insignificant in the subsample of stocks that experience a negative information shock, but remains significant in the subsample of stocks where there is no negative information release (Panel B, Table 8).

\section{Mutual Fund Security Lending and Portfolio Decision}

Both the univariate and multivariate analyses present evidence consistent with the idea that institutional investors are willing to purchase high fee shares to gain lending income. In this section, I will focus on the willingness to purchase shares with increasing lending fees of a particular set of institutional investors, namely mutual funds. Following Evans, Ferreira, and Prado (2012), I examine the security lending practices and portfolio decisions of mutual funds to determine whether mutual funds are more likely to allow 
security lending if the aggregate lending fee was high in the previous month and how an increase in lending fee influences their portfolio allocations.

Evans, Ferreira, and Prado (2012) examine security lending practices of mutual funds and their impact on performance, using a sample of 2,093 active and 186 passive equity funds over the 1996-2008 period. They collect the N-SAR-B annual fund filings, from the SEC's Edgar database. The N-SAR form provides information on whether or not a fund is allowed by its prospectus to lend securities and whether or not it actually lends equities.

If institutional investors are buying high fee stocks for the purpose of lending, there will be a positive relation between allowing a security lending program and the level of lending fees. For the sample period between 2002 and 2008 I obtain aggregate monthly value weighted average lending fees from Data Explorers and match that to the data of Evans, Ferreira, and Prado (2012) to test whether the aggregate lending income in the previous month is an important predictor of whether a mutual fund will allow security lending. In line with Evans, Ferreira, and Prado (2012) I include both family level controls like family size, lagged average family performance rank, the Herfindahl index of total net assets (TNA) in each Morningstar investment objective, average active share, family flow, family expense ratio and the percentage of index, subadvised and broker funds in the family, and fund level controls as fund size, turnover, age, active share and lagged performance rank. ${ }^{16}$ Column 1 through 4 of Table 9 reports the odds following a logit regression of the likelihood of allowing a security lending program for the sample period 2002-2008 (columns 1-2) and the period under study 2006-2008 (columns 3-4).

The aggregate lending fee is indeed an important predictor, as a $1 \%$ increase in lending fee makes mutual funds 3.10 times more likely of allowing security lending for

\footnotetext{
${ }^{16}$ The results are robust to just the inclusion of fund level controls or just family controls. For more details on the data sources I refer to Evans, Ferreira, and Prado (2012).
} 
the sample period 2002-2008 and 1.92 times for the period 2006-2008. In columns 2 and $4 \mathrm{I}$ introduce fund fixed effects and the identification will thus come from the funds that experienced a change in security lending allowance. In the Evans, Ferreira, and Prado (2012) sample period, $17.81 \%$ of active funds and $38.5 \%$ of index funds switch from prohibiting to allowing security lending. Less than $3 \%$ of the active and index funds switch from allowing to prohibiting security lending. So while changes are not uncommon the introduction of fixed effects does significantly lower the number of observations. Column 2 shows that funds that changed their security lending practice are 2.9 times more likely to allow security lending if the fee in the previous month is as high as $1 \%$ in the sample period 2002-2008. For the subsample 2006-2008 the odds of allowing security lending when changing the lending status is as high as 9.5 times.

For mutual funds the security lending fee seems to be an important reason for allowing a security lending program. This is consistent with anecdotal evidence that mutual funds are shifting their lending strategy from volume-oriented in which funds lend out a large percentage of easy-to-find securities towards value lending, a strategy involving lending only those securities that generate significant revenues. ${ }^{17}$ However, the question remains whether they would buy a stock for the purpose of gaining lending income. To address this question, I look at the underlying holdings of mutual funds and test whether an increase in lending fee would lead to an increased likelihood of a fund increasing their holdings in that particular stock. The holdings data is from the Mutual Fund Holdings Database from Thomson Financial.

Table 10 reports the results of a logit regression of the likelihood of a mutual fund increasing the holdings in a stock. I include the same control variables as in the previous institutional holdings regressions; size, MTB, age, standard deviation of returns, S\&P 500 indicator, bid-ask spread, turnover, price, number of analysts, past return and whether the stock pays dividends. To account for seasonal changes in the holdings I also

\footnotetext{
${ }^{17}$ Vanguard Research: Security Lending is still no free lunch, July 2011.
} 
include period fixed effects. In line with the findings on institutional investors in general, the first column in Table 10 shows that mutual funds are 1.70 times more likely to increase their holdings in a stock if the stock has experienced an increase in lending fee. In the second column, I introduce fund-stock pair fixed effects to capture the variation within the portfolio and the results are even stronger. When changing their portfolio holdings, mutual funds are two times more likely to increase their allocation to stocks with increasing fees. The findings are in line with a quote from the securities lending handbook of 2011: "Within the securities lending world, the basic premise is that you have to buy the underlying securities and lend them out." - Beneficial Owner \& Pension Fund Securities Lending Handbook 2011, page 16.

\section{Alternative Interpretation}

An alternative interpretation of the results is that institutional investors are covering their short sale positions and are caught in a so-called "short squeeze". That is institutions holding short positions are forced to purchase shares when the price increases rapidly, in order to exit their short position. In October 2008, a short squeeze temporarily drove the shares of Volkswagen on the Xetra DAX from $€ 210.85$ to over $€ 1000$ in under two days. ${ }^{18}$

To rule out this possibility, I rerun the trading and return analysis, now controlling for the level of short interest. Conceivably, if institutional investors are forced to close their positions, the maximum amount they will need to buy is the amount of outstanding shorts. Alternatively, I use the percentage of shares borrowed as reported by Data Explorers. The inclusion of short interest in Table 1 of the appendix, (columns 1-3, Panel A), does not reduce the economic effect of the response in institutional ownership, as the coefficients on the dummy fee increase remain economically significant. Moreover,

\footnotetext{
${ }^{18}$ http://www.guardian.co.uk/business/2008/oct/29/vw-volkswagen-short-selling.
} 
short interest reduces neither the number of institutions holding the stock in response to a fee increase nor the likelihood that the stock will be bought. In columns 4-6, I include the number of shares borrowed as a proxy for the number of stocks to be covered in the event of a squeeze. The effect of a fee increase on the change in institutional ownership (column 4), on the number of institutional investors (column 5), and on the probability of purchase (column 6) remains significant.

In an alternative test, I split the sample of stocks into large and small on the basis of market capitalization, as short squeezes are more frequent among small-capitalization stocks. A stock is classified as small-cap if its market capitalization is below $\$ 2$ billion, and large if its market capitalization is higher than $\$ 10$ billion.

In Panel $\mathrm{B}$ of Table 1 of the appendix, I examine the relation between the fee increase dummy and institutional trading separately for large- and small-capitalization stocks. The response of institutional investors to an increase in lending fee is much more pronounced for the larger stocks, in terms of the increase in holdings, and the likelihood of purchase. The effect is about twice as strong for larger stocks than for small-capitalization ones. The effect of an increase in the fee is only larger for smaller stocks for the number of institutions holding the stock.

The fact that total institutional ownership does not increase for small-capitalization stocks and that the likelihood of purchase is economically smaller provides evidence that my results are not driven by any squeeze on small-capitalization stocks. The results mostly come from the larger stocks in the sample, where a short squeeze is less likely to occur.

In Table 2 of the appendix, I test whether the return results are robust to the inclusion of short interest or loan quantity (Panel A). The inclusion of both short interest (columns 1-3) or loan quantity (columns 4-6) does not reduce the significance of the interaction between institutional buying and the return on high fee stocks. Once I account 
for the level of short selling, the annualized risk-adjusted return difference between the high fee stocks that are previously bought by institutions and high fee stocks that were not is $4.39 \%(0.366 \times 12)$.

In Panel B, I split the sample again in small-and large-capitalization stocks. If a short squeeze is responsible for the findings, I would expect a greater overvaluation effect for small-capitalization stocks, where a squeeze is much more likely. The premium on high fee stocks versus low fee stocks is still higher when the stocks were acquired in the previous quarter by institutional investors, but the premium is only significant for the larger-capitalization stocks, further providing support against a short squeeze as driving the results.

\section{Conclusion}

By lending shares to short sellers, institutional investors benefit by receiving lending income. In 2008, institutions made $\$ 1.5$ billion this way. In this study I test the Duffie, Gârleanu, and Pedersen (2002) hypothesis that security prices incorporate expected future securities lending income. To determine whether institutional investors anticipate gains from future lending of securities, I examine their trading behavior around changes in loan fees.

Impulse-response functions following a panel VAR show that a one standard deviation increase in the lending fee increases institutional ownership by $0.50 \%$ and the number of institutions holding the stock by $0.90 \%$ in the following quarter. This suggests that institutions buy shares in response to an increase in lending fees and that this could explain the premium associated with high lending fee stocks.

In effect, the overvaluation associated with high lending fees is most pronounced among stocks that institutional investors are trading in the direction of the high fee 
possibly to gain lending income. For example, among stocks with intense institutional trading, the average contemporaneous four-factor alpha spread between high and low fee stocks is $2.78 \%$ per month (t-statistic $=3.52$ ). Among stocks with low institutional trading, the risk-adjusted return spread between high and low fee stocks is actually negative and statistically significant. When including firm level controls in a FamaMacbeth specification the difference in risk-adjusted return between a high fee stock that is bought by institutional investors and a top fee quintile stock that is not bought by institutions is $2.64 \%$ per year.

Overall, this study identifies an important mechanism that drives the overvaluation of high fee stocks by showing that institutional investors trade in the direction of the high fee to gain lending income and thereby contribute to the overvaluation. The results further imply that overpricing caused by the presence of short sale constraints is partly a result of capitalized lending income. 


\section{References}

Aitken, M.J.; A. Frino; M.S. McCorry; and P.L. Swan. "Short Sales Are Almost Instantaneously Bad News: Evidence from the Australian Stock Exchange." Journal of Finance, 53 (1998), 2205-2223.

Arellano, M.; S. Bond. "Some tests of specification for panel data: Monte Carlo evidence and an application to employment equations." The Review of Economic Studies, 58 (1991), 277297.

Arellano, M.; O. Bover. "Another look at the instrumental variables estimation of error-components models." Journal of Econometrics 68 (1995), 29-51.

Asquith, P.; P.A.Pathak; and J.R. Ritter. "Short interest, institutional ownership, and stock returns." Journal of Financial Economics 78 (2005), 243-276.

Autore, D.M.; T.J. Boulton; and M.V. Braga-Alves. "Failures to deliver, short sale constraints, and stock overvaluation." Working paper (2010). Miami University.

Blocher, J.; A.V. Reed; and E.D. Vab Wesep. "Connecting two markets: An equilibrium framework for shorts, longs and stock loans." Forthcoming Journal of Financial Economics (2012).

Blundell, R.; S. Bond. "Initial conditions and moment restrictions in dynamic panel data models." Journal of Econometrics 87 (1998), 11-143.

Boehme, R.D.; B.R. Danielsen; and S.M. Sorescu. "Short-sale constraints, differences of opinion, and overvaluation." Journal of Financial and Quantitative Analysis 41 (2006), 455-487.

Boehmer, E.; C.M. Jones; and X. Zhang. "Which Shorts Are Informed?" Journal of Finance 63 (2008), 491-527.

Boehmer, E.; C.M. Jones; and X. Zhang. "What do short sellers know?" Working Paper (2011).

Boehmer, E.; Z.R. Huszár; and B.D. Jordan. "The good news in short interest." Journal of Financial Economics 96 (2010), 80-97.

Brent, A.; D. Morse; and E.K. Stice. "Short Interest: Explanations and Tests." Journal of Financial and Quantitative Analysis 25 (1990), 273-289. $57-82$.

Carhart, M. M.; "On persistence in mutual fund performance." Journal of Finance 52 (1997),

Chen, J.; H. Hong; and J.C. Stein. "Breadth of ownership and stock returns." Journal of Financial Economics 66 (2002), 171-205.

Christophe, S.E.; M.G. Ferri; and J.J. Angel. "Short selling prior to earnings announcements." Journal of Finance 59 (2004), 1845-1875.

Christophe, S.E.; M.G. Ferri; and J. Hsieh. "Informed trading before analyst downgrades: Evidence from short sellers." Journal of Financial Economics 95 (2010), 85-106.

Cohen, L.; K.B. Diether; and C.J. Malloy. "Supply and Demand Shifts in the Shorting Market." Journal of Finance 62 (2007), 2061-2096.

Cremers, M.; A. Petajisto. "How active is your fund manager? A new measure that predicts performance." Review of Financial Studies 22 (2009), 3329-3365.

D'Avolio, G. "The market for borrowing stock." Journal of Financial Economics 66 (2002), 341360. 
Dechow, P.M.; A.P. Hutton; L. Meulbroek; and R.G. Sloan. "Short-sellers, fundamental analysis and stock returns." Journal of Financial Economics 61 (2001), 77-106.

Desai, H.; K. Ramesh; S.R. Thiagarajan; and B.V. Balachandran. "An investigation of the informational role of short interest in the NASDAQ market." Journal of Finance 57 (2002), 2263-2287.

Diamond, D.W.; and R.E. Verrecchia. "Constraints on short-selling and asset price adjustment to private information." Journal of Financial Economics 18 (1987), 277-311.

Diether, K.B.; K. Lee.; and I.M. Werner; "Short-sale strategies and return predictability." The Review of Financial Studies 22 (2008), 575-607.

Duffie, D. "Special repo rates." Journal of Finance 51 (1996), 493-526.

Duffie, D.; N. Gârleanu; and L.H. Pedersen. "Securities lending, shorting and pricing." Journal of Financial Economics 66 (2002), 307-339.

Evans, R.B.; M.A. Ferreira; M. Porras Prado. "Equity Lending, Investment Restrictions and Fund Performance." Working paper (2012).

Evans, R.B.; C.C. Geczy; D.K. Musto; and A.V. Reed. "Failure is an option: impediments to short selling and options prices." The Review of Financial Studies 22 (2009), 1955-1980.

Fama, E.; and J. MacBeth. "Risk, return and equilibrium: empirical tests." Journal of Political Economy 81 (1973), 607-636.

Figlewski, S. "The informational effects of restrictions on short sales: Some empirical evidence." Journal of Financial and Quantitative Analysis 16 (1981), 463-476.

Geczy, C.; C.D.K. Musto; and A.V. Reed. "Stocks are special too: An analysis of the equity lending market." Journal of Financial Economics 66 (2002), 241-269.

Gompers, P.A.; and A. Metrick. "Institutional investors and equity prices." Quarterly Journal of Economics 116 (2001), 229-259.

Harrison, J.M.; and D.M. Kreps. "Speculative investor behavior in a stock market with heterogenous expectations." Quarterly Journal of Economics 92 (1978), 323-336.

Hong, H.; J. Scheinkman; and W. Xiong. "Asset float and speculative bubbles." Journal of Finance 61 (2006), 1073-1117.

Jiang, H. "Institutional investors, intangible information and the book-to-market effect." Journal of Financial Economics 96 (2009), 98-126.

Jones, C.M.; and O.A. Lamont. "Short-sale constraints and stock returns." Journal of Financial Economics 66 (2002), 207239.

Kaplan, S.N.; T.J. Moskowitz; and B.A. Sensoy. "The effects of stock lending on security prices: An experiment." Forthcoming Journal of Finance (2012).

Karpoff, J.M.; and X. Lou. "Short sellers and financial misconduct." Journal of Finance 65 (2010), 1879-1913.

Kolasinski, A.C.; A.V. Reed; and M.C. Ringgenberg. "A multiple lender approach to understand supply and search in the equity lending market." Forthcoming Journal of Finance (2012).

Lamont, O. A.; "Go down fighting: Short sellers vs. firms." Review of Asset Pricing Studies, 2 (2012), 1-30.

Love, I.; and L. Zicchino "Financial development and dynamic investment behavior: Evidence from 
panel VAR." The Quarterly Review of Economics and Finance 46 (2006), 190-210.

Miller, E. "Risk, uncertainty, and divergence of opinion." Journal of Finance 32 (1977), 1151-1168.

Morris, S. "Speculative investor behavior and learning." Journal of Financial Economics 111 (1996), 1111-1133.

Nagel, S. "Short sales, institutional investors and the cross-section of stock returns." Journal of Financial Economics 78 (2005), 277-309.

Prado, M.P.; Saffi, P.A.C.; and J. Sturgess. "Equity lending markets and ownership structure." Working Paper (2012).

Scheinkman, J.; and W. Xiong. "Overconfidence and speculative bubbles." Journal of Political Economy 111 (2003), 1183-1219.

Senchank, A.J.; and L.T. Starks. "Short-sale restrictions and market reaction to short interest announcements." Journal of Financial and Quantitative Analysis 28 (1993), 177-194.

Seneca, J.J. "Short interest: Bearish or bullish?" Journal of Finance 22 (1967), 67-70.

Yan, X.S.; and Z. Zhang. "Institutional investors and equity returns: Are short-term institutions better informed?" The Review of Financial Studies 22 (2009), 893-924. 
Appendix Variable Description

\begin{tabular}{|c|c|c|}
\hline Variable & Definition & Source \\
\hline $\mathrm{IO}$ & $\begin{array}{l}\text { Institutional investor ownership. } \\
\text { The number of shares held by } \\
\text { institutional investors divided by } \\
\text { the total number of shares out- } \\
\text { standing. Observations with to- } \\
\text { tal institutional ownership greater } \\
\text { than } 100 \% \text { excluded. }\end{array}$ & $\begin{array}{l}\text { The institutional holdings data } \\
\text { are from CDA/Spectrum. The } \\
\text { data about stock prices and re- } \\
\text { turns come from the Center } \\
\text { for Research in Security Prices } \\
\text { (CRSP). }\end{array}$ \\
\hline Number of Institutions (NIO) & $\begin{array}{l}\text { Number of institutional investors } \\
\text { holding the shares. }\end{array}$ & CDA/Spectrum. \\
\hline$\Delta \mathrm{IO}$ & $\begin{array}{l}\text { First difference of institutional } \\
\text { ownership (IO). }\end{array}$ & CDA/Spectrum. \\
\hline$(\Delta \ln (1+\mathrm{NIO}))$ & $\begin{array}{l}\text { First difference of the natural log } \\
\text { of one plus the number of institu- } \\
\text { tional investors. }\end{array}$ & CDA/Spectrum. \\
\hline Fee & $\begin{array}{l}\text { Weekly value-weighted average } \\
\text { fee. }\end{array}$ & Data Explorers \\
\hline$\Delta$ Fee & First difference of fee. & Data Explorers \\
\hline Fee increase & $\begin{array}{l}\text { Dummy variable equal to one if } \\
\text { the loan fee increased. }\end{array}$ & Data Explorers \\
\hline On Loan & $\begin{array}{l}\text { Quantity of borrowed securities as } \\
\text { a percentage of shares outstand- } \\
\text { ing. }\end{array}$ & Data Explorers \\
\hline Short Interest & $\begin{array}{l}\text { Total of outstanding shorted } \\
\text { shares. }\end{array}$ & Shortsqueeze.com \\
\hline Utilization & $\begin{array}{l}\text { Value of assets on loan from ben- } \\
\text { eficial owners relative to the lend- } \\
\text { able asset value. }\end{array}$ & Data Explorers \\
\hline Inventory & $\begin{array}{l}\text { Available inventory quantity from } \\
\text { beneficial owners as a percentage } \\
\text { of shares outstanding. }\end{array}$ & Data Explorers \\
\hline Inventory Accounts & $\begin{array}{l}\text { Total number of inventory ac- } \\
\text { counts. Separate count for each } \\
\text { row of inventory held by each un- } \\
\text { derlying beneficial owner or fund } \\
\text { that owns the security. }\end{array}$ & Data Explorers \\
\hline Active Agents & $\begin{array}{l}\text { Number of custodians with open } \\
\text { transactions. }\end{array}$ & Data Explorers \\
\hline Failure Occurrence & $\begin{array}{l}\text { Total cumulative occurrence of } \\
\text { fails-to-deliver for the specific time } \\
\text { period. }\end{array}$ & Federal Reserve website. \\
\hline Continue on next page & & \\
\hline
\end{tabular}




\begin{tabular}{|c|c|c|}
\hline Variable & Definition & Source \\
\hline Mcap & $\begin{array}{l}\text { Market Capitalization. Price } \mathrm{x} \\
\text { shares outstanding. }\end{array}$ & CRSP \\
\hline MTB & $\begin{array}{l}\text { Market-to-book ratio. Market } \\
\text { capitalization divided by the book } \\
\text { value for the fiscal year ended be- } \\
\text { fore the most recent June } 30 \text {. }\end{array}$ & Compustat/CRSP \\
\hline Bid-Ask & $\begin{array}{l}\text { Difference between the closing bid } \\
\text { and ask quotes for a security over } \\
\text { the security price. }\end{array}$ & CRSP \\
\hline Turnover & Volume over shares outstanding. & CRSP \\
\hline Price & Share price. & CRSP \\
\hline S\&P 500 & $\begin{array}{l}\text { Dummy variable that equals one } \\
\text { if a company is in the S\&P } 500 \\
\text { index. }\end{array}$ & $\begin{array}{l}\text { Compustat Annual Updates Index } \\
\text { Constituents }\end{array}$ \\
\hline Age & $\begin{array}{l}\text { Firm age calculated as the number } \\
\text { of years since first returns appear } \\
\text { in CRSP. }\end{array}$ & CRSP \\
\hline Stdev & $\begin{array}{l}\text { Volatility, measured as the stan- } \\
\text { dard deviation of monthly returns } \\
\text { over a year. }\end{array}$ & $\begin{array}{l}\text { Monthly price and return data } \\
\text { from CRSP }\end{array}$ \\
\hline Ret & Quarterly stock return. & \\
\hline Four-Factor Alpha & $\begin{array}{l}\text { Monthly Carhart (1997) four- } \\
\text { factor alpha with factor loadings } \\
\text { estimated over the prior three } \\
\text { years using monthly data. The al- } \\
\text { phas are winsorized at } 1 \% \text { to min- } \\
\text { imize the impact of outliers. } \\
\text { Dummy that equals one if the } \\
\text { stock is in the top fee quintile. }\end{array}$ & \\
\hline Dividend & $\begin{array}{l}\text { Dummy variable that equals one } \\
\text { if institutional investors purchased } \\
\text { the stock in the previous quarter. } \\
\text { Dummy variable that equals one if } \\
\text { the firm pays dividends. }\end{array}$ & Compustat \\
\hline Negative Earnings & $\begin{array}{l}\text { Dummy variable that equals one } \\
\text { if the firm has announced nega- } \\
\text { tive earnings, as reported in the } \\
\text { unadjusted surprise history file in } \\
\text { I/B/E/S. }\end{array}$ & $\begin{array}{l}\text { Unadjusted surprise history file in } \\
\mathrm{I} / \mathrm{B} / \mathrm{E} / \mathrm{S}\end{array}$ \\
\hline Negative Surprise & $\begin{array}{l}\text { Announced earnings in excess of } \\
\text { the analysts' consensus forecasts. } \\
\text { Equals one if the earnings surprise } \\
\text { is negative. }\end{array}$ & $\begin{array}{l}\text { Unadjusted surprise history file in } \\
\mathrm{I} / \mathrm{B} / \mathrm{E} / \mathrm{S}\end{array}$ \\
\hline NumAnalyst & $\begin{array}{l}\text { Number of analysts following the } \\
\text { stock, as reported in the un- } \\
\text { adjusted surprise history file in } \\
\text { I/B/E/S. Missing values are set to } \\
\text { zero. }\end{array}$ & $\begin{array}{l}\text { Unadjusted surprise history file in } \\
\mathrm{I} / \mathrm{B} / \mathrm{E} / \mathrm{S}\end{array}$ \\
\hline
\end{tabular}


Table 1

\section{Descriptive Statistics}

This table presents the descriptive statistics (Panel A) of the variables used in this study. Panel B reports the average differences between stocks with annualized lending fees below $1 \%$ and stocks with fees above $1 \%$ and the test of equality of the means ( $t$-test) and medians (Wilcoxon) across both groups. The details of data sources and variable definitions are in the appendix.

\begin{tabular}{lcccccc}
\hline \multicolumn{1}{l}{ Panel A: Sample Descriptive } & Statistics & & & & \\
& $\mathrm{N}$ & Mean & $\mathrm{p} 25$ & Median & $\mathrm{p} 75$ & Stdev \\
\hline IO (\%) & 30642 & 54.24 & 28.98 & 57.74 & 80.43 & 29.45 \\
NIO (\%) & 30642 & 139.53 & 28.00 & 77.00 & 160.00 & 194.52 \\
$\Delta$ IO & 30642 & 0.57 & -1.82 & 0.29 & 2.87 & 7.44 \\
ln (1+NIO) & 30642 & 2.47 & -6.41 & 0.86 & 9.33 & 21.57 \\
Fee (\%) & 25468 & 0.99 & 0.14 & 0.17 & 0.55 & 2.60 \\
Fee increase & 30642 & 0.35 & 0.00 & 0.00 & 1.00 & 0.48 \\
$\Delta$ Fee & 30642 & -0.01 & -0.04 & 0.00 & 0.03 & 1.24 \\
On Loan (\%) & 30642 & 4.20 & 0.35 & 2.40 & 6.15 & 5.09 \\
Short Interest (\%) & 30642 & 4.07 & 0.02 & 1.80 & 6.31 & 5.81 \\
Utilization (\%) & 30642 & 21.92 & 2.60 & 13.15 & 33.73 & 23.77 \\
Inventory (\%) & 30642 & 15.23 & 5.77 & 14.86 & 23.32 & 10.51 \\
Inventory Accounts & 30642 & 331.35 & 39.67 & 176.00 & 403.67 & 462.95 \\
Active Agents & 30642 & 25.01 & 4.00 & 21.00 & 38.00 & 23.58 \\
Failure (\%) & 9264 & 0.23 & 0.03 & 0.08 & 0.21 & 0.59 \\
Failure Occurrence & 30642 & 0.54 & 0.00 & 0.00 & 1.00 & 0.97 \\
Mcap & 30642 & $4,196,263$ & 99,428 & 353,076 & $1,615,062$ & $18,700,000$ \\
MTB & 30642 & 1.44 & 0.37 & 0.90 & 1.74 & 2.47 \\
Bid-Ask (\%) & 30642 & 0.02 & 0.00 & 0.00 & 0.00 & 0.66 \\
Turnover (\%) & 30642 & 180.51 & 44.19 & 123.44 & 235.64 & 224.38 \\
Price & 30642 & 23.21 & 6.69 & 15.12 & 30.20 & 43.24 \\
S\&P 500 (\%) & 30642 & 0.02 & 0.00 & 0.00 & 0.00 & 0.13 \\
Age & 30642 & 15.89 & 4.00 & 11.00 & 22.00 & 16.26 \\
Ret (\%) & 30642 & -2.93 & -9.60 & 0.00 & 3.34 & 14.20 \\
Dividend & 30642 & 0.38 & 0.00 & 0.00 & 1.00 & 0.49 \\
Stdev (\%) & 30642 & 33.65 & 19.33 & 30.98 & 46.20 & 20.39 \\
NumAnalyst & 30642 & 17.86 & 3.00 & 12.00 & 26.00 & 19.31 \\
\hline Continue on next page & & & & & \\
\hline & & & & & & \\
\hline
\end{tabular}




\begin{tabular}{lccccc}
\hline Panel B: Differences between High and Low Fee Stocks & & \\
& Low Fee & High Fee & & t-test & Wilcoxon \\
& Stocks & Stocks & Difference & p-value & p-value \\
\hline IO (\%) & 62.76 & 36.81 & -25.95 & 0.00 & 0.00 \\
NIO (\%) & 178.90 & 59.02 & -119.88 & 0.00 & 0.00 \\
$\Delta$ IO & 0.52 & 0.69 & 0.17 & 0.06 & 0.49 \\
ln (1+NIO) & 1.63 & 4.19 & 2.56 & 0.85 & 0.80 \\
Fee (\%) & 0.21 & 4.26 & 4.05 & 0.00 & 0.00 \\
Fee increase & 0.39 & 0.27 & -0.12 & 0.00 & 0.00 \\
$\Delta$ Fee & -0.15 & 0.27 & 0.42 & 0.00 & 0.00 \\
On Loan (\%) & 4.34 & 3.93 & -0.41 & 0.00 & 0.00 \\
Short Interest (\%) & 3.94 & 4.33 & 0.39 & 0.00 & 0.00 \\
Utilization (\%) & 17.70 & 30.57 & 12.88 & 0.00 & 0.00 \\
Inventory (\%) & 18.78 & 7.97 & -10.81 & 0.00 & 0.00 \\
Inventory Accounts & 434.66 & 120.01 & -314.65 & 0.00 & 0.00 \\
Active Agents & 29.81 & 15.19 & -14.62 & 0.00 & 0.00 \\
Failure (\%) & 0.11 & 0.35 & 0.24 & 0.00 & 0.00 \\
Failure Occurrence & 0.33 & 0.97 & 0.64 & 0.00 & 0.00 \\
Mcap & $5,819,798$ & 875,123 & $-4,944,675$ & 0.00 & 0.00 \\
MTB & 1.31 & 1.71 & 0.39 & 0.00 & 0.03 \\
Bid-Ask (\%) & 0.02 & 0.02 & 0.00 & 0.53 & 0.01 \\
Turnover (\%) & 195.93 & 148.96 & -46.97 & 0.00 & 0.00 \\
Price & 28.55 & 12.27 & -16.28 & 0.00 & 0.00 \\
S\&P 500 (\%) & 0.02 & 0.00 & -0.02 & 0.00 & 0.00 \\
Age & 19.78 & 10.45 & -9.33 & 0.00 & 0.00 \\
Ret (\%) & -2.49 & -3.84 & -1.35 & 0.00 & 0.00 \\
Dividend & 0.46 & 0.23 & -0.22 & 0.00 & 0.00 \\
Stdev (\%) & 32.52 & 35.97 & 3.44 & 0.00 & 0.00 \\
NumAnalyst & 21.72 & 9.97 & 11.75 & 0.00 & 0.00 \\
\hline & & & & & \\
\hline
\end{tabular}


Table 2

\section{Institutional Ownership Trading around Fee increases in a Panel VAR}

The panel VAR approach is a multivariate simultaneous equation system that treats all variables as endogenous, while allowing for unobserved firm heterogeneity. The lag length of 1 was selected following the AIC. The specification of the first-order VAR is as follows:

$$
y_{i t}=\Upsilon_{0}+\Upsilon_{1} y_{i t-1}+f_{i}+d_{t}+\epsilon_{i t}
$$

where $y_{i t}$ is a vector including the change in institutional ownership $(\Delta I O)$, and the annualized lending fee in Panel A. In Panel B, I include the quarterly stock return to control for changes in stock price, which might lead to changes in short sellers' demand and in turn lending fees and institutional ownership. $f_{i}$ introduces stock fixed effects and $d_{t}$ period-specific time dummies. In Panel $\mathrm{C}$ and $\mathrm{D}$, the $y_{i t}$ vector includes changes in the natural $\log$ of one plus the number of institutional investors $(\Delta \ln (1+N I O))$. Panel $\mathrm{C}$ is the two-variable panel VAR, while Panel D includes the stock return. Fee is the average percentage short sale fee and Ret is the quarterly stock return. Robust $t-$ statistics are reported, ${ }^{* * *} p<0.01,{ }^{* *} p<0.05,{ }^{*} p<0.1$. The details of data sources and variable definitions are in the appendix.

\begin{tabular}{|c|c|c|c|c|c|}
\hline \multicolumn{3}{|c|}{ Panel A: $\Delta$ IO VAR analysis } & \multicolumn{3}{|c|}{ Panel C: $\Delta \ln (1+$ NIO $)$ VAR analysis } \\
\hline \multirow{2}{*}{\multicolumn{3}{|c|}{ Dependent variable: $\Delta \mathrm{IO}_{t}$}} & \multicolumn{3}{|c|}{ Dependent variable: $\Delta \ln (1+\mathrm{NIO})_{t}$} \\
\hline & & & & Coefficient & t-statistic \\
\hline$\Delta \mathrm{IO}_{t-1}$ & $-0.315^{* * *}$ & -24.14 & $\Delta \ln (1+\mathrm{NIO})_{t-1}$ & $-0.211^{* * *}$ & -7.37 \\
\hline $\mathrm{Fee}_{t-1}$ & $0.366^{* *}$ & 2.71 & $\mathrm{Fee}_{t-1}$ & $0.660^{* *}$ & 2.51 \\
\hline \multicolumn{3}{|c|}{ Dependent variable: $\mathrm{Fee}_{t}$} & \multicolumn{3}{|c|}{ Dependent variable: Fee $_{t}$} \\
\hline & Coefficient & t-statistic & & Coefficient & t-statistic \\
\hline$\Delta \mathrm{IO}_{t-1}$ & $-0.005^{* * *}$ & -3.39 & $\Delta \ln (1+\mathrm{NIO})_{t-1}$ & $-0.003^{* * *}$ & -4.52 \\
\hline $\mathrm{Fee}_{t-1}$ & $0.239 * * *$ & 3.58 & $\mathrm{Fee}_{t-1}$ & $0.241^{* * *}$ & 3.94 \\
\hline \multicolumn{3}{|c|}{ Panel B: $\Delta$ IO VAR analysis } & \multicolumn{3}{|c|}{ Panel D: $\Delta \ln (1+$ NIO $)$ VAR analysis } \\
\hline \multicolumn{3}{|c|}{ Dependent variable: $\Delta \mathrm{IO}_{t}$} & \multicolumn{3}{|c|}{ Dependent variable: $\Delta \ln (1+\mathrm{NIO})_{t}$} \\
\hline & Coefficient & t-statistic & & Coefficient & t-statistic \\
\hline$\Delta \mathrm{IO}_{t-1}$ & $-0.326 * * *$ & -24.55 & $\Delta \ln (1+\mathrm{NIO})_{t-1}$ & $-0.213^{* * *}$ & -10.07 \\
\hline $\mathrm{Fee}_{t-1}$ & $0.514^{* * *}$ & 4.27 & $\mathrm{Fee}_{t-1}$ & $0.947^{* * *}$ & 3.55 \\
\hline $\operatorname{Ret}_{t-1}$ & $-1.028^{* * *}$ & -6.49 & $\operatorname{Ret}_{t-1}$ & -0.624 & -1.30 \\
\hline \multicolumn{3}{|c|}{ Dependent variable: $\mathrm{Fee}_{t}$} & \multicolumn{3}{|c|}{ Dependent variable: $\mathrm{Fee}_{t}$} \\
\hline & Coefficient & t-statistic & & Coefficient & t-statistic \\
\hline$\Delta \mathrm{IO}_{t-1}$ & $-0.005^{* * *}$ & -3.36 & $\Delta \ln (1+\mathrm{NIO})_{t-1}$ & $-0.004^{* * *}$ & -4.69 \\
\hline $\mathrm{Fee}_{t-1}$ & $0.280^{* * *}$ & 4.37 & $\mathrm{Fee}_{t-1}$ & $0.285^{* * *}$ & 4.83 \\
\hline $\operatorname{Ret}_{t-1}$ & -0.222 & -0.59 & $\operatorname{Ret}_{t-1}$ & -0.231 & -0.57 \\
\hline \multicolumn{3}{|c|}{ Dependent variable: $\operatorname{Ret}_{t}$} & \multicolumn{3}{|c|}{ Dependent variable: Ret $_{t}$} \\
\hline & Coefficient & t-statistic & & Coefficient & t-statistic \\
\hline$\Delta \mathrm{IO}_{t-1}$ & $-0.001^{* * *}$ & -3.18 & $\Delta \mathrm{IO}_{t-1}$ & $-0.001^{* * *}$ & -5.59 \\
\hline $\mathrm{Fee}_{t-1}$ & 0.003 & 0.64 & $\mathrm{Fee}_{t-1}$ & 0.004 & 0.86 \\
\hline $\operatorname{Ret}_{t-1}$ & 0.008 & 0.45 & $\operatorname{Ret}_{t-1}$ & 0.008 & 0.47 \\
\hline
\end{tabular}


Table 3

\section{Institutional Ownership Trading behavior around Fee increases}

Panel regression of institutional ownership and trading on an indicator variable of fee increase and stock specific control variables and year dummies. Panel data are U.S. common equity stock from the last quarter of 2006 to the last quarter of 2008. Column 5 reports the odds of buying a stock following a logit specification, where a buy is defined as an increase in institutional ownership. Results are reported in percentages. Robust $t$-statistics in parentheses, ${ }^{* * *} p<0.01,{ }^{* *} p<0.05,{ }^{*} p<0.1$. The details of data sources and variable definitions are in the appendix.

\begin{tabular}{|c|c|c|c|c|c|}
\hline & $\begin{array}{l}(1) \\
\mathrm{IO}_{t} \\
\end{array}$ & $\begin{array}{c}(2) \\
\ln \\
(1+\mathrm{NIO})_{t}\end{array}$ & $\begin{array}{c}(3) \\
\Delta \\
\mathrm{IO}_{t} \\
\end{array}$ & $\begin{array}{c}(4) \\
\Delta \ln \\
(1+\mathrm{NIO})_{t}\end{array}$ & $\begin{array}{c}(5) \\
\text { Odds } \\
\text { Buyt }\end{array}$ \\
\hline Fee increase $_{t, t-1}$ & $\begin{array}{c}0.975^{* * *} \\
(10.81)\end{array}$ & $\begin{array}{c}1.888^{* * *} \\
(7.96)\end{array}$ & $\begin{array}{c}0.887^{* * *} \\
(8.74)\end{array}$ & $\begin{array}{c}1.395^{* * *} \\
(5.31)\end{array}$ & $\begin{array}{c}1.334^{* * *} \\
(10.36)\end{array}$ \\
\hline $\operatorname{Ln}(\text { Mcap })_{t}$ & $\begin{array}{c}5.046^{* * *} \\
(15.40)\end{array}$ & $\begin{array}{c}25.122^{* * *} \\
(26.01)\end{array}$ & $\begin{array}{c}2.596^{* * *} \\
(13.77)\end{array}$ & $\begin{array}{c}8.608^{* * *} \\
(16.06)\end{array}$ & $\begin{array}{c}2.065^{* * *} \\
(14.41)\end{array}$ \\
\hline Bid-Ask $_{t}$ & $\begin{array}{c}0.268^{* *} \\
(2.56)\end{array}$ & $\begin{array}{c}-0.263^{* * *} \\
(-3.34)\end{array}$ & $\begin{array}{l}0.029 \\
(0.41)\end{array}$ & $\begin{array}{c}0.185^{* * *} \\
(3.61)\end{array}$ & $\begin{array}{c}0.995 \\
(-0.27)\end{array}$ \\
\hline Turnover $_{t}$ & $\begin{array}{c}0.003^{* * *} \\
(4.64)\end{array}$ & $\begin{array}{l}0.002^{*} \\
(1.77)\end{array}$ & $\begin{array}{l}0.000 \\
(0.08)\end{array}$ & $\begin{array}{l}0.001 \\
(1.28)\end{array}$ & $\begin{array}{l}1.000 \\
(0.69)\end{array}$ \\
\hline Price $_{t}$ & $\begin{array}{l}-0.009 \\
(-1.04)\end{array}$ & $\begin{array}{c}0.038^{* *} \\
(1.99)\end{array}$ & $\begin{array}{l}-0.005 \\
(-1.60)\end{array}$ & $\begin{array}{l}0.021^{*} \\
(1.88)\end{array}$ & $\begin{array}{c}0.998 \\
(-1.56)\end{array}$ \\
\hline $\mathrm{S} \& \mathrm{P} 500_{t}$ & $\begin{array}{l}2.750 \\
(0.63)\end{array}$ & $\begin{array}{l}7.737 \\
(0.86)\end{array}$ & $\begin{array}{l}0.904 \\
(0.76)\end{array}$ & $\begin{array}{c}9.540^{* * *} \\
(3.64)\end{array}$ & $\begin{array}{l}1.255 \\
(0.56)\end{array}$ \\
\hline $\mathrm{Age}_{t}$ & $\begin{array}{l}0.225 \\
(1.28)\end{array}$ & $\begin{array}{c}0.967^{*} \\
(1.75)\end{array}$ & $\begin{array}{l}-0.086 \\
(-0.50)\end{array}$ & $\begin{array}{l}-0.763 \\
(-0.89)\end{array}$ & $\begin{array}{c}0.945^{* *} \\
(-2.10)\end{array}$ \\
\hline $\operatorname{Stdev}_{t}$ & $\begin{array}{l}-0.002 \\
(-0.42)\end{array}$ & $\begin{array}{c}0.113^{* * *} \\
(6.81)\end{array}$ & $\begin{array}{c}-0.045^{* * *} \\
(-10.09)\end{array}$ & $\begin{array}{c}-0.122^{* * *} \\
(-8.50)\end{array}$ & $\begin{array}{c}0.989^{* * *} \\
(-10.06)\end{array}$ \\
\hline $\operatorname{Return}_{t-1}$ & $\begin{array}{c}-0.055^{* * *} \\
(-16.53)\end{array}$ & $\begin{array}{c}-0.188^{* * *} \\
(-19.58)\end{array}$ & $\begin{array}{c}-0.012^{* * * *} \\
(-3.64)\end{array}$ & $\begin{array}{c}-0.028^{* * *} \\
(-3.09)\end{array}$ & $\begin{array}{c}0.997^{* * * *} \\
(-3.05)\end{array}$ \\
\hline $\mathrm{MTB}_{t}$ & $\begin{array}{c}-0.582^{* * *} \\
(-5.28)\end{array}$ & $\begin{array}{c}-2.577^{* * * *} \\
(-6.29)\end{array}$ & $\begin{array}{l}0.025 \\
(0.42)\end{array}$ & $\begin{array}{l}0.265 \\
(1.48)\end{array}$ & $\begin{array}{c}0.983 \\
(-1.21)\end{array}$ \\
\hline Dividend $_{t}$ & $\begin{array}{c}0.941^{* * *} \\
(3.09)\end{array}$ & $\begin{array}{c}3.389^{* * *} \\
(4.17)\end{array}$ & $\begin{array}{l}-0.041 \\
(-0.18)\end{array}$ & $\begin{array}{l}-0.824 \\
(-1.21)\end{array}$ & $\begin{array}{c}1.201^{* *} \\
(2.36)\end{array}$ \\
\hline NumAnalyst $_{t}$ & $\begin{array}{c}0.270^{* * *} \\
(11.33)\end{array}$ & $\begin{array}{c}0.858^{* * *} \\
(12.31)\end{array}$ & $\begin{array}{c}-0.104^{* * *} \\
(-7.52)\end{array}$ & $\begin{array}{c}-0.416^{* * *} \\
(-7.89)\end{array}$ & $\begin{array}{c}0.981^{* * *} \\
(-5.88)\end{array}$ \\
\hline Stock Fixed Effects & Yes & Yes & Yes & Yes & Yes \\
\hline Year Fixed Effects & Yes & Yes & Yes & Yes & Yes \\
\hline Observations & 30,642 & 30,642 & 30,642 & 30,642 & 29,681 \\
\hline Number of stocks & 4,040 & 4,040 & 4,040 & 4,040 & 3,621 \\
\hline$R^{2} /$ Psuedo $R^{2}$ & $11.69 \%$ & $19.34 \%$ & $4.02 \%$ & $5.39 \%$ & $3.89 \%$ \\
\hline
\end{tabular}




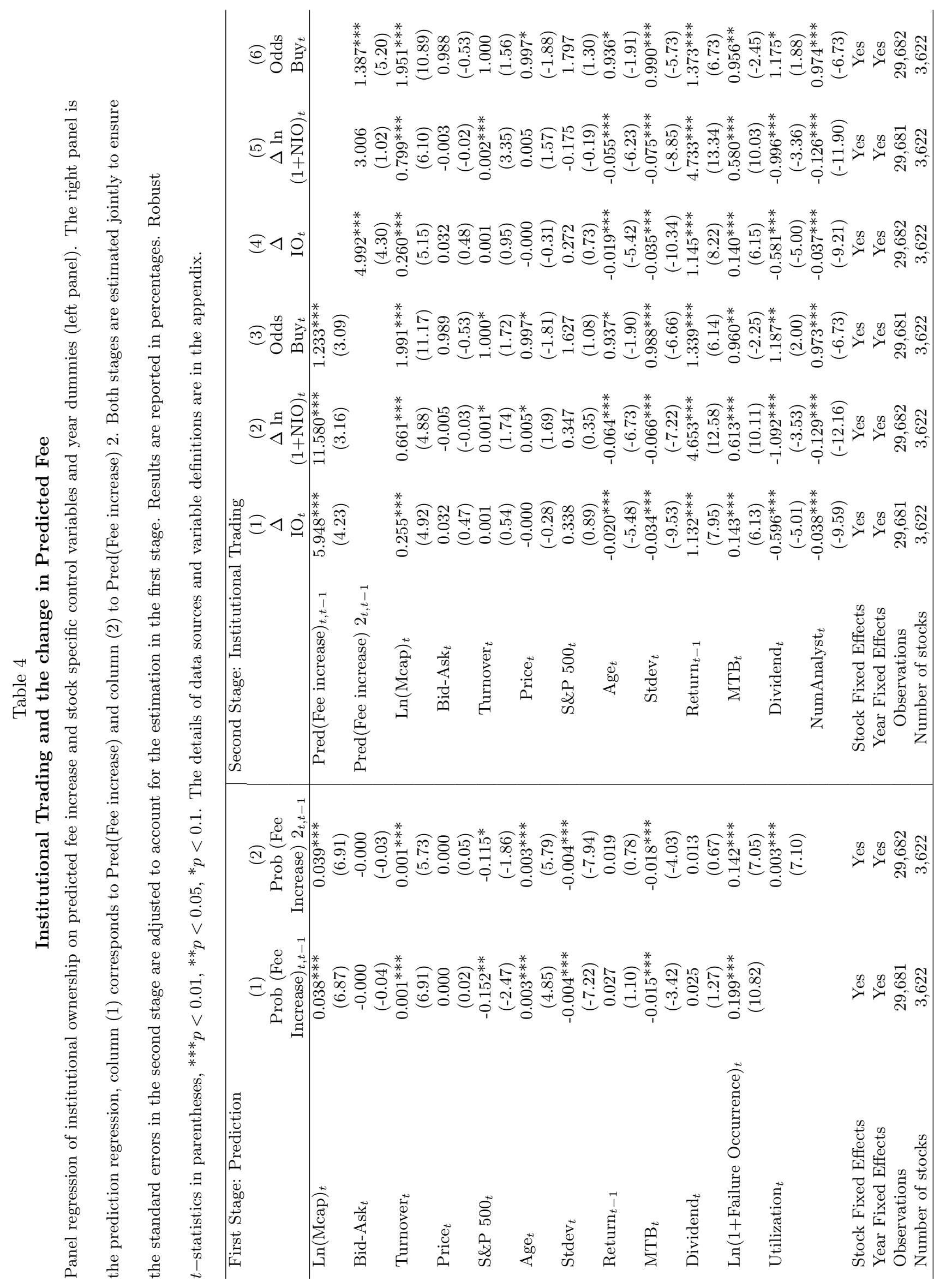


Table 5

\section{Institutional Trading and Fee: Independent sort}

The stocks are sorted each month into five equal weight portfolios using the lending fee and change in institutional ownership with respect to the previous quarter. The first two institutional ownership quintiles represent an average decrease in ownership and as of quintile 3 the average change is an increase in holdings, which is increasing in quintiles 4 and 5. The time-series averages of equal-weighted daily return and factor model alphas are reported in percentages. The alphas are the intercepts from the one (CAPM) in panel B, and Carhart 4 factor model in panel C. The t-statistics are Newey West adjusted for 5 lags and shown in parentheses below the coefficient estimates. ${ }^{* * *} p<0.01,{ }^{* *} p<0.05,{ }^{*} p<0.1$.

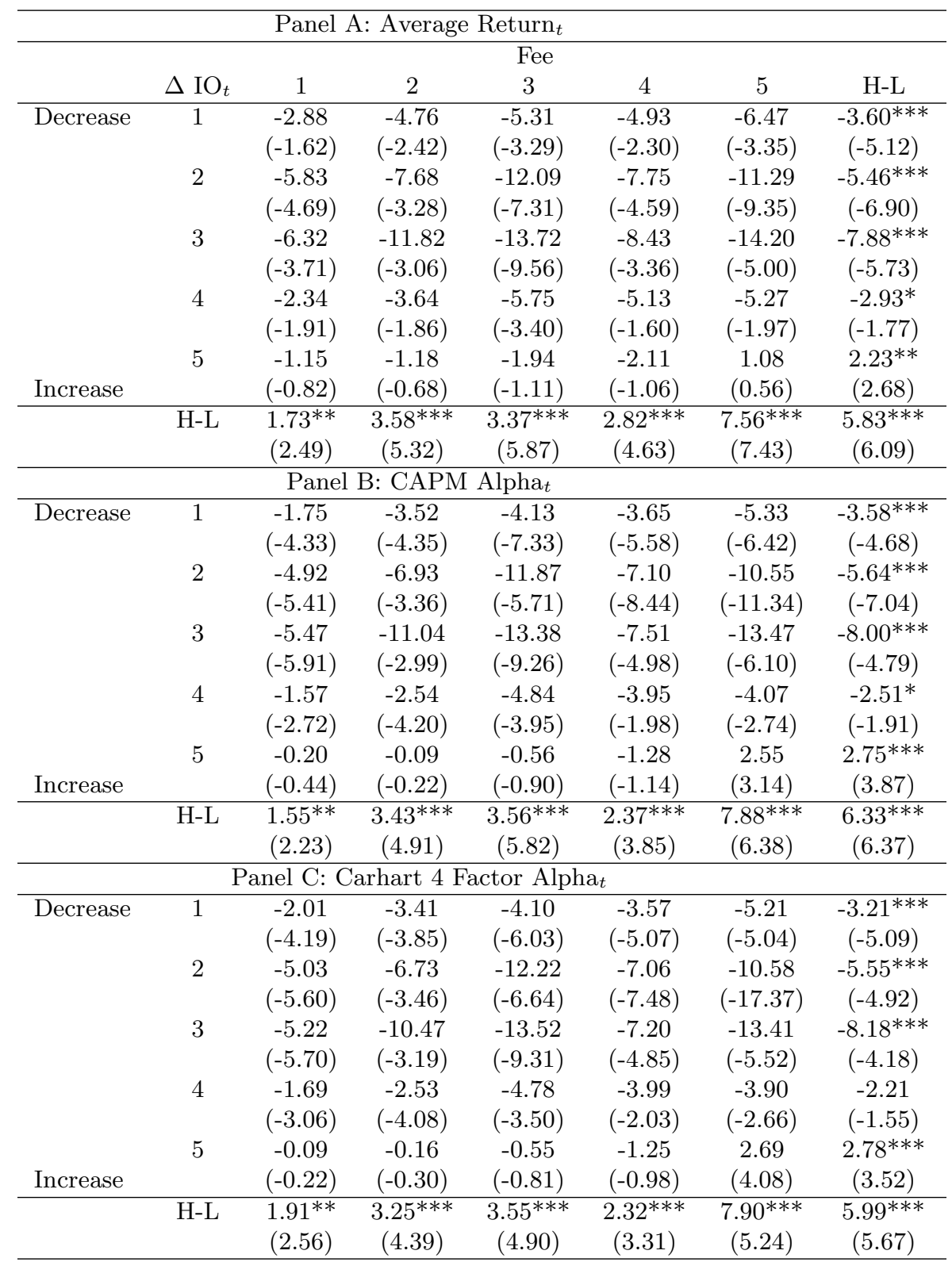


Table 6

\section{Abnormal return and Institutional Buying}

Fama Macbeth regression explaining the Carhart (1997) four-factor alpha with factor loadings estimated over the prior three years using monthly data. The alphas are winsorized at $1 \%$ to minimize the impact of outliers. The reported results are in percentages. Stocks are classified as Special $_{t}$ if they belong to the highest fee quintile. $\widehat{\text { pecial }}_{t}$ is an indicator variable that equals one if the stock is ranked as the highest predicted fee quintile. I predict the lending fee as a function of the occurrence of a failure-to-deliver and stock characteristics like size, MTB, age, standard deviation of returns, S\&P 500 indicator, bid-ask spread, turnover, price, past return and whether the stock pays dividends. The second prediction used for $\widehat{\text { pecial }} 2_{t}$ includes proprietary information on utilization levels as reported by Data Explorers. Robust $t$-statistics in parentheses, ${ }^{* * *} p<0.01,{ }^{* *} p<0.05$,

${ }^{*} p<0.1$. The details of data sources and remaining variable definitions are in the appendix.

\begin{tabular}{|c|c|c|c|c|}
\hline & $(1)$ & $(2)$ & $(3)$ & $(4)$ \\
\hline $\mathrm{Buy}_{t}$ & $\begin{array}{l}-0.053 \\
(-1.36)\end{array}$ & & & \\
\hline Special $_{t}$ & $\begin{array}{c}-0.209^{* *} \\
(-2.21)\end{array}$ & $\begin{array}{c}-0.313^{* * *} \\
(-4.22)\end{array}$ & & \\
\hline Special $_{t} *$ Buy $_{t}$ & $\begin{array}{c}0.224^{*} \\
(1.81)\end{array}$ & & & \\
\hline $\mathrm{Buy}_{t-1}$ & & $\begin{array}{l}-0.040 \\
(-0.95)\end{array}$ & $\begin{array}{l}-0.000 \\
(-0.00)\end{array}$ & $\begin{array}{l}0.009 \\
(0.28)\end{array}$ \\
\hline $\operatorname{Special}_{t} *$ Buy $_{t-1}$ & & $\begin{array}{c}0.362^{* *} \\
(2.58)\end{array}$ & & \\
\hline$\widehat{\text { Special }}_{t}$ & & & $\begin{array}{l}-0.159 \\
(-1.62)\end{array}$ & \\
\hline$\widehat{S p e c i a l}_{t} * \mathrm{Buy}_{t-1}$ & & & $\begin{array}{c}0.190 * * \\
(2.15)\end{array}$ & \\
\hline Special $_{t} 2$ & & & & $\begin{array}{c}-0.346^{* * *} \\
(-2.98)\end{array}$ \\
\hline Special $_{t} 2 *$ Buy $_{t-1}$ & & & & $\begin{array}{l}0.180 \\
(1.55)\end{array}$ \\
\hline $\ln (\mathrm{MCAP})_{t}$ & $\begin{array}{l}-0.004 \\
(-0.09)\end{array}$ & $\begin{array}{l}-0.008 \\
(-0.17)\end{array}$ & $\begin{array}{l}-0.002 \\
(-0.03)\end{array}$ & $\begin{array}{l}-0.011 \\
(-0.25)\end{array}$ \\
\hline Bid-Ask $_{t}$ & $\begin{array}{c}0.117^{* * *} \\
(3.19)\end{array}$ & $\begin{array}{c}0.116^{* * *} \\
(3.17)\end{array}$ & $\begin{array}{c}0.118^{* * *} \\
(3.23)\end{array}$ & $\begin{array}{c}0.113^{* * *} \\
(3.16)\end{array}$ \\
\hline Turnover $_{t}$ & $\begin{array}{c}0.013^{* * *} \\
(2.88)\end{array}$ & $\begin{array}{c}0.013^{* * *} \\
(2.86)\end{array}$ & $\begin{array}{c}0.013^{* * *} \\
(3.02)\end{array}$ & $\begin{array}{c}0.014^{* * *} \\
(3.20)\end{array}$ \\
\hline $\mathrm{S} \& \mathrm{P} 500_{t}$ & $\begin{array}{l}0.021 \\
(0.25)\end{array}$ & $\begin{array}{l}0.022 \\
(0.26)\end{array}$ & $\begin{array}{l}0.020 \\
(0.24)\end{array}$ & $\begin{array}{l}0.015 \\
(0.18)\end{array}$ \\
\hline $\mathrm{MTB}_{t}$ & $\begin{array}{l}0.011 \\
(0.52)\end{array}$ & $\begin{array}{l}0.011 \\
(0.51)\end{array}$ & $\begin{array}{l}0.012 \\
(0.58)\end{array}$ & $\begin{array}{l}0.016 \\
(0.72)\end{array}$ \\
\hline Dividend $_{t}$ & $\begin{array}{c}-0.257^{* * *} \\
(-3.90)\end{array}$ & $\begin{array}{c}-0.265^{* * *} \\
(-3.97)\end{array}$ & $\begin{array}{c}-0.259^{* * *} \\
(-3.95)\end{array}$ & $\begin{array}{c}-0.263^{* * *} \\
(-3.97)\end{array}$ \\
\hline NumAnalyst $_{t}$ & $\begin{array}{c}-0.018^{* * *} \\
(-3.18)\end{array}$ & $\begin{array}{c}-0.018^{* * *} \\
(-3.26)\end{array}$ & $\begin{array}{c}-0.018^{* * *} \\
(-3.37)\end{array}$ & $\begin{array}{c}-0.018^{* * *} \\
(-3.13)\end{array}$ \\
\hline Constant & $\begin{array}{l}0.353 \\
(0.52)\end{array}$ & $\begin{array}{l}0.399 \\
(0.60)\end{array}$ & $\begin{array}{l}0.282 \\
(0.43)\end{array}$ & $\begin{array}{l}0.432 \\
(0.67)\end{array}$ \\
\hline Observations & 66,011 & 62,010 & 62,010 & 62,010 \\
\hline$R^{2}$ & $7.39 \%$ & $3.48 \%$ & $3.51 \%$ & $3.68 \%$ \\
\hline
\end{tabular}


Table 7

\section{Negative Information Trade-Off}

Panel (U.S. common equity stock from June 2006 to December 2008) logit regression of an increase in institutional ownership (buy) on loan fee increase and stock specific control variables and year dummies. Results are reported in odds. The first measure is an indicator variable that equals one if the company announces negative earnings (Negative Earnings $s_{i t}$ ). The second measure equals one if the earnings surprise, the announced earnings in excess of the analysts consensus forecasts, is negative (Negative Surprise ${ }_{i t}$ ). The details of data sources and variable definitions are in the appendix. Robust $t$-statistics in parentheses. ${ }^{* * *} p<0.01,{ }^{* *} p<0.05,{ }^{*} p<0.1$.

\begin{tabular}{|c|c|c|c|c|}
\hline & $(1)$ & $(2)$ & $(3)$ & $(4)$ \\
\hline Fee increase int $_{t-1}$ & $\begin{array}{c}1.363^{* * *} \\
(10.28)\end{array}$ & & $\begin{array}{c}1.355^{* * *} \\
(10.17)\end{array}$ & \\
\hline Negative Earnings $_{t}$ & $\begin{array}{c}0.959 \\
(-0.71)\end{array}$ & $\begin{array}{c}0.925 \\
(-1.52)\end{array}$ & & \\
\hline Negative Earnings ${ }_{t}{ }^{*}$ Fee increase $e_{t, t-1}$ & $\begin{array}{l}0.882^{*} \\
(-1.73)\end{array}$ & & & \\
\hline$\Delta \mathrm{Fee}_{t, t-1}$ & & $\begin{array}{l}1.085^{* * *} \\
(6.44)\end{array}$ & & $\begin{array}{c}1.077^{* * *} \\
(6.08)\end{array}$ \\
\hline Negative Earnings ${ }_{t} * \Delta \mathrm{Fee}_{t, t-1}$ & & $\begin{array}{c}0.923^{* * *} \\
(-3.69)\end{array}$ & & \\
\hline Negative Surprise $_{t}$ & & & $\begin{array}{l}1.002 \\
(0.04)\end{array}$ & $\begin{array}{c}0.971 \\
(-0.51)\end{array}$ \\
\hline Negative Surprise $_{t}{ }^{*}$ Fee increase $t, t-1$ & & & $\begin{array}{c}0.899 \\
(-1.42)\end{array}$ & \\
\hline Negative Surprise $_{t} * \Delta$ Fee ${ }_{t, t-1}$ & & & & $\begin{array}{c}0.936^{* * *} \\
(-2.98)\end{array}$ \\
\hline $\operatorname{Ln}(\text { Mcap })_{t}$ & $\begin{array}{c}2.049 * * * \\
(14.23)\end{array}$ & $\begin{array}{c}2.075^{* * *} \\
(14.48)\end{array}$ & $\begin{array}{c}2.057^{* * *} \\
(14.30)\end{array}$ & $\begin{array}{c}2.082^{* * *} \\
(14.55)\end{array}$ \\
\hline Bid-Ask $_{t}$ & $\begin{array}{c}0.994 \\
(-0.29)\end{array}$ & $\begin{array}{c}0.993 \\
(-0.35)\end{array}$ & $\begin{array}{c}0.994 \\
(-0.28)\end{array}$ & $\begin{array}{c}0.993 \\
(-0.33)\end{array}$ \\
\hline Turnover $_{t}$ & $\begin{array}{l}1.000 \\
(0.72)\end{array}$ & $\begin{array}{l}1.000 \\
(0.89)\end{array}$ & $\begin{array}{l}1.000 \\
(0.67)\end{array}$ & $\begin{array}{l}1.000 \\
(0.85)\end{array}$ \\
\hline Price $_{t}$ & $\begin{array}{l}0.998 \\
(-1.57)\end{array}$ & $\begin{array}{c}0.997 \\
(-1.56)\end{array}$ & $\begin{array}{c}0.998 \\
(-1.55)\end{array}$ & $\begin{array}{l}0.998 \\
(-1.54)\end{array}$ \\
\hline $\mathrm{S} \& \mathrm{P} 500_{t}$ & $\begin{array}{l}1.254 \\
(0.55)\end{array}$ & $\begin{array}{l}1.203 \\
(0.46)\end{array}$ & $\begin{array}{l}1.262 \\
(0.57)\end{array}$ & $\begin{array}{l}1.216 \\
(0.48)\end{array}$ \\
\hline Age $_{t}$ & $\begin{array}{c}0.944^{* *} \\
(-2.12)\end{array}$ & $\begin{array}{c}0.947^{* *} \\
(-2.05)\end{array}$ & $\begin{array}{c}0.944^{* *} \\
(-2.11)\end{array}$ & $\begin{array}{c}0.947^{* *} \\
(-2.03)\end{array}$ \\
\hline $\operatorname{Stdev}_{t}$ & $\begin{array}{c}0.989 * * * \\
(-10.07)\end{array}$ & $\begin{array}{c}0.989 * * * \\
(-10.61)\end{array}$ & $\begin{array}{c}0.989^{* * *} \\
(-10.05)\end{array}$ & $\begin{array}{c}0.989^{* * *} \\
(-10.59)\end{array}$ \\
\hline $\operatorname{Return}_{t-1}$ & $\begin{array}{c}0.998^{* * *} \\
(-3.00)\end{array}$ & $\begin{array}{c}0.997^{* * *} \\
(-2.86)\end{array}$ & $\begin{array}{c}0.998^{* * *} \\
(-3.03)\end{array}$ & $\begin{array}{c}0.997^{* * *} \\
(-2.88)\end{array}$ \\
\hline $\mathrm{MTB}_{t}$ & $\begin{array}{c}0.984 \\
(-1.18)\end{array}$ & $\begin{array}{c}0.984 \\
(-1.17)\end{array}$ & $\begin{array}{c}0.983 \\
(-1.19)\end{array}$ & $\begin{array}{c}0.983 \\
(-1.20)\end{array}$ \\
\hline Dividend $_{t}$ & $\begin{array}{c}1.198^{* *} \\
(2.33)\end{array}$ & $\begin{array}{c}1.199 * * \\
(2.35)\end{array}$ & $\begin{array}{c}1.200^{* *} \\
(2.36)\end{array}$ & $\begin{array}{c}1.199 * * \\
(2.35)\end{array}$ \\
\hline NumAnalyst $_{t}$ & $\begin{array}{c}0.981 * * * \\
(-5.81)\end{array}$ & $\begin{array}{c}0.911^{* * *} \\
(-5.66)\end{array}$ & $\begin{array}{c}0.980 * * * \\
(-5.84)\end{array}$ & $\begin{array}{c}0.981^{* * *} \\
(-5.71)\end{array}$ \\
\hline Stock Fixed Effects & Yes & Yes & Yes & Yes \\
\hline Year Fixed Effects & Yes & Yes & Yes & Yes \\
\hline Observations & 29,681 & 29,681 & 29,681 & 29,681 \\
\hline Number of stocks & 3,621 & 3,621 & 3,621 & 3,621 \\
\hline Pseudo $R^{2}$ & $3.91 \%$ & $3.67 \%$ & $3.89 \%$ & $3.65 \%$ \\
\hline
\end{tabular}


Table 8

\section{Abnormal Return and Institutional Buying in the Negative News subsample}

Fama Macbeth regression explaining the Carhart (1997) 4-factor alpha with factor loadings estimated over the prior three years using monthly data. The alphas are winsorized at $1 \%$ to minimize the impact of outliers. The reported results are in percentages. Panel A reports the results for the sample of stocks with negative earnings news. The first subsample is of companies announcing negative earnings, as reported in the unadjusted surprise history file in I/B/E/S. The second sample is for stocks with announced earnings short of the analysts consensus forecasts. Panel B reports the results for the sample of stocks with no negative earnings news. Stocks are classified as Special $_{t}$ if they belong to the highest fee quintile. $\widehat{\text { ppecial }}_{t}$ is an indicator variable that equals one if the stock is ranked as the highest predicted fee quintile, the fee is predicted as a function of the occurrence of a failure-to-deliver and stock characteristics like size, MTB, age, standard deviation of returns, S\&P 500 indicator, bid-ask spread, turnover, price, past return, number of analysts and whether the stock pays dividends. The second prediction used for $\widehat{\text { Special }} 2_{t}$ includes proprietary information on utilization levels as reported by Data Explorers. Robust $t$-statistics in parentheses, ${ }^{* * *} p<0.01,{ }^{* *} p<0.05,{ }^{*} p<0.1$. Continue on next page. 
Continued from Previous Page

\begin{tabular}{|c|c|c|c|c|c|c|}
\hline \multicolumn{7}{|c|}{ Panel A: Negative News Subsample } \\
\hline \multirow{3}{*}{ Buyt $_{t-1}$} & (1) & $(2)$ & $(3)$ & (4) & $(5)$ & $(6)$ \\
\hline & -0.110 & -0.035 & 0.060 & 0.064 & 0.029 & 0.067 \\
\hline & $(-0.90)$ & $(-0.38)$ & $(0.57)$ & $(0.81)$ & $(0.27)$ & $(1.00)$ \\
\hline \multirow[t]{2}{*}{ Special $_{t}$} & -0.216 & $-0.425^{* * *}$ & & & & \\
\hline & $(-1.70)$ & $(-3.74)$ & & & & \\
\hline \multirow[t]{2}{*}{ Special $_{t} *$ Buy $_{t-1}$} & 0.339 & 0.359 & & & & \\
\hline & $(1.37)$ & $(1.64)$ & & & & \\
\hline \multirow[t]{2}{*}{$\widehat{S p e c i a l}_{t}$} & & & $-0.275^{* *}$ & -0.141 & & \\
\hline & & & $(-2.13)$ & $(-0.90)$ & & \\
\hline \multirow{2}{*}{$\operatorname{Special}_{t} * \mathrm{Buy}_{t-1}$} & & & 0.094 & 0.115 & & \\
\hline & & & $(0.44)$ & $(0.66)$ & & \\
\hline \multirow[t]{2}{*}{ Special $2_{t}$} & & & & & -0.202 & $-0.347^{* *}$ \\
\hline & & & & & $(-1.70)$ & $(-2.61)$ \\
\hline \multirow{2}{*}{\multicolumn{2}{|c|}{$\operatorname{Special}_{t} * \mathrm{Buy}_{t-1}$}} & & & & 0.015 & 0.133 \\
\hline & & & & & $(0.10)$ & $(0.85)$ \\
\hline Controls & Yes & Yes & Yes & Yes & Yes & Yes \\
\hline \multirow[t]{2}{*}{ Negative News } & Earnings & Earnings & Earnings & Earnings & Earnings & Earnings \\
\hline & & Surprise & & Surprise & Earnings & Surprise \\
\hline Observations & 8,979 & 23,125 & 8,979 & 23,125 & 8,979 & 23,125 \\
\hline Pseudo $R^{2}$ & $6.47 \%$ & $3.86 \%$ & $6.41 \%$ & $3.91 \%$ & $6.40 \%$ & $3.92 \%$ \\
\hline \multicolumn{7}{|c|}{ Panel B: No Negative News Subsample } \\
\hline & $(1)$ & $(2)$ & $(3)$ & & & \\
\hline \multirow[t]{2}{*}{ Buy $_{t-1}$} & -0.031 & -0.012 & 0.001 & & & \\
\hline & $(-0.82)$ & $(-0.36)$ & $(0.02)$ & & & \\
\hline Special $_{t}$ & $\begin{array}{c}-0.403^{* * *} \\
(-4.03)\end{array}$ & & & & & \\
\hline $\mathrm{Special}_{t} * \mathrm{Buy}_{t-1}$ & $\begin{array}{c}0.428^{* *} \\
(2.31)\end{array}$ & & & & & \\
\hline \multirow[t]{2}{*}{$\widehat{\text { Special }}_{t}$} & & -0.167 & & & & \\
\hline & & $(-1.31)$ & & & & \\
\hline $\operatorname{Special}_{t} *$ Buy $_{t-1}$ & & $\begin{array}{c}0.238^{*} \\
(1.98)\end{array}$ & & & & \\
\hline \multirow[t]{2}{*}{ Special $2_{t}$} & & & $-0.443^{* * *}$ & & & \\
\hline & & & $(-3.43)$ & & & \\
\hline \multirow[t]{2}{*}{$\operatorname{Special}_{t} * \mathrm{Buy}_{t-1}$} & & & $0.277^{*}$ & & & \\
\hline & & & $(2.03)$ & & & \\
\hline Controls & Yes & Yes & Yes & & & \\
\hline Observations & 53,031 & 53,031 & 53,031 & & & \\
\hline Pseudo $R^{2}$ & $3.75 \%$ & $3.82 \%$ & $3.96 \%$ & & & \\
\hline
\end{tabular}


Table 9

\section{Mutual Fund Security Lending Decision}

The table shows the odds following a logit regressions of the fund decision to allow security lending using fund family and fund characteristics as explanatory variables. The data is from Evans, Ferreira, and Prado (2012). Security Lending Allowed is a dummy variable that equals one if a fund is allowed to lend shares and zero otherwise (N-SAR form question 70N). TNA is the fund's total net assets in $\$$ millions. Family TNA is the sum of the total net assets of management company in $\$$ millions. Average Family Performance Rank is the average of the performance rank of funds in the fund family. Average Family Expense Ratio is the average expense ratio of funds in the fund family. Investment Objective Herfindahl is a herfindahl of the Morningstar investment objective of funds in the fund family. Family Net Flow is the average net flow of funds in the fund family. Average Family Active Share is the average active share of funds in the fund family. Index Funds in Family is the percentage of index funds in the fund family. Subadvised in Family is the percentage of subadvised funds in the fund family. Broker Funds in Family is the percentage of funds sold through brokers as measured by the presence of a front load, rear load or $12 \mathrm{~b} 1$ above $0.25 \%$ in the fund family. Turnover is the ratio of aggregated sales or aggregated purchases of securities divided by the average 12-month total net assets of the fund. Active Share refers to the active share measure of Cremers and Petajisto (2009). Performance Rank is the rank quintile

within investment style using 36-month of past fund returns. Age is measured as the current date minus the first offer date. Robust $t$-statistics in parentheses, ${ }^{* * *} p<0.01,{ }^{* *} p<0.05,{ }^{*} p<0.1$. Continue on next page. 
Continued from Previous Page

\begin{tabular}{|c|c|c|c|c|}
\hline & $(1)$ & $(2)$ & $(3)$ & $(4)$ \\
\hline Aggregate Fee $t-1$ & $\begin{array}{c}3.102^{* * *} \\
(6.14)\end{array}$ & $\begin{array}{c}2.887^{* * *} \\
(6.55)\end{array}$ & $\begin{array}{c}1.917^{* * *} \\
(3.78)\end{array}$ & $\begin{array}{c}9.492^{* * *} \\
(6.20)\end{array}$ \\
\hline $\log (\text { Family TNA })_{t}$ & $\begin{array}{c}1.066^{* *} \\
(2.07)\end{array}$ & $\begin{array}{c}0.986 \\
(-0.37)\end{array}$ & $\begin{array}{c}1.133^{* * *} \\
(3.39)\end{array}$ & $\begin{array}{c}4.626^{* * *} \\
(10.02)\end{array}$ \\
\hline Average Family Performance Rank R $_{t-1}$ & $\begin{array}{l}0.958^{*} \\
(-1.68)\end{array}$ & $\begin{array}{c}0.959 \\
(-1.22)\end{array}$ & $\begin{array}{c}0.899 \text { *** } \\
(-3.06)\end{array}$ & $\begin{array}{c}0.700^{* * * *} \\
(-4.86)\end{array}$ \\
\hline Investment Objective Herfindahl $_{t}$ & $\begin{array}{c}0.991 * * * \\
(-3.62)\end{array}$ & $\begin{array}{c}0.999 \\
(-0.06)\end{array}$ & $\begin{array}{c}0.993^{* *} \\
(-2.37)\end{array}$ & $\begin{array}{c}0.996 \\
(-0.54)\end{array}$ \\
\hline Average Family Active Share $_{t}$ & $\begin{array}{l}0.986^{*} \\
(-1.94)\end{array}$ & $\begin{array}{c}0.973^{* * *} \\
(-4.21)\end{array}$ & $\begin{array}{c}0.992 \\
(-0.80)\end{array}$ & $\begin{array}{c}0.825^{* * *} \\
(-8.08)\end{array}$ \\
\hline Family Flow $t$ & $\begin{array}{c}0.982^{* * *} \\
(-3.85)\end{array}$ & $\begin{array}{c}0.965^{* * *} \\
(-7.30)\end{array}$ & $\begin{array}{c}0.999 \\
(-0.02)\end{array}$ & $\begin{array}{c}0.968^{* *} \\
(-2.57)\end{array}$ \\
\hline$\%$ Index Funds in Family ${ }_{t}$ & $\begin{array}{c}1.039^{* * *} \\
(3.78)\end{array}$ & $\begin{array}{c}1.032^{* * *} \\
(2.69)\end{array}$ & $\begin{array}{c}1.046^{* * *} \\
(4.01)\end{array}$ & $\begin{array}{c}0.879 * * * \\
(-3.04)\end{array}$ \\
\hline$\%$ Sudadvised in Family $_{t}$ & $\begin{array}{c}0.986^{* * *} \\
(-9.66)\end{array}$ & $\begin{array}{c}1.027^{* * *} \\
(16.82)\end{array}$ & $\begin{array}{c}0.989^{* * *} \\
(-6.12)\end{array}$ & $\begin{array}{c}0.918^{* * *} \\
(-13.49)\end{array}$ \\
\hline$\%$ Broker Funds in Family $t$ & $\begin{array}{c}0.996 \\
(-1.24)\end{array}$ & $\begin{array}{l}0.996^{*} \\
(-1.87)\end{array}$ & $\begin{array}{l}1.000 \\
(0.02)\end{array}$ & $\begin{array}{l}1.012 \\
(1.62)\end{array}$ \\
\hline Average Family Expense Ratio $t$ & $\begin{array}{l}1.338 \\
(1.48)\end{array}$ & $\begin{array}{c}0.189^{* * *} \\
(-9.59)\end{array}$ & $\begin{array}{c}1.630^{* *} \\
(1.97)\end{array}$ & $\begin{array}{c}0.001^{* * *} \\
(-11.04)\end{array}$ \\
\hline $\ln (\text { Age })_{t}$ & $\begin{array}{c}0.697^{* * *} \\
(-4.70)\end{array}$ & $\begin{array}{c}1.172^{\text {*** }} \\
(2.69)\end{array}$ & $\begin{array}{c}0.744^{* * *} \\
(-3.33)\end{array}$ & $\begin{array}{c}4.768^{* * *} \\
(7.39)\end{array}$ \\
\hline Turnover $_{t}$ & $\begin{array}{c}1.02 \\
(0.28)\end{array}$ & $\begin{array}{c}1.512^{* * *} \\
(10.29)\end{array}$ & $\begin{array}{c}0.989 \\
(-0.25)\end{array}$ & $\begin{array}{c}5.462^{* * *} \\
(12.11)\end{array}$ \\
\hline Active Share $_{t}$ & $\begin{array}{l}1.002 \\
(0.57)\end{array}$ & $\begin{array}{c}0.973^{* * *} \\
(-8.19)\end{array}$ & $\begin{array}{l}1.002 \\
(0.59)\end{array}$ & $\begin{array}{c}0.948^{* * *} \\
(-4.85)\end{array}$ \\
\hline $\ln (\mathrm{TNA})_{t}$ & $\begin{array}{c}0.889^{* * *} \\
(-3.00)\end{array}$ & $\begin{array}{c}0.968 \\
(-1.01)\end{array}$ & $\begin{array}{c}0.842^{* * *} \\
(-3.60)\end{array}$ & $\begin{array}{c}0.697^{* * *} \\
(-2.89)\end{array}$ \\
\hline Fund Performance Rank R $_{t-1}$ & $\begin{array}{c}0.992 \\
(-0.55)\end{array}$ & $\begin{array}{c}0.967^{* *} \\
(-2.56)\end{array}$ & $\begin{array}{l}1.005 \\
(0.28)\end{array}$ & $\begin{array}{c}0.936 * * \\
(-2.47)\end{array}$ \\
\hline Fund Fixed Effects & No & Yes & No & Yes \\
\hline Subsample & $2002-2008$ & $2002-2008$ & 2006-2008 & $2006-2008$ \\
\hline Observations & 107267 & 20577 & 49820 & 5528 \\
\hline Number of Funds & 1999 & 300 & 1721 & 161 \\
\hline
\end{tabular}


Table 10

\section{Mutual Fund Portfolio Decision}

The table reports the odds following a logit regression of the likelihood of a mutual fund increasing their holdings in a stock. The holdings data is from the Mutual Fund Holdings Database from Thomson Financial. Robust $t$-statistics in parentheses, ${ }^{* * *} p<0.01,{ }^{* *} p<0.05,{ }^{*} p<0.1$.

\begin{tabular}{|c|c|c|}
\hline & (1) & $(2)$ \\
\hline Fee increase int $_{t-1}$ & $\begin{array}{c}1.700^{* *} \\
(2.33)\end{array}$ & $\begin{array}{c}2.009^{* * *} \\
(15.86)\end{array}$ \\
\hline $\operatorname{Ln}(\text { Mcap })_{t}$ & $\begin{array}{l}1.022 \\
(1.56)\end{array}$ & $\begin{array}{c}1.176^{* * *} \\
(16.65)\end{array}$ \\
\hline Bid-Ask $_{t}$ & $\begin{array}{c}0.998^{* * *} \\
(-3.35)\end{array}$ & $\begin{array}{l}1.001 \\
(1.48)\end{array}$ \\
\hline Turnover $_{t}$ & $\begin{array}{c}1.011^{* * *} \\
(3.36)\end{array}$ & $\begin{array}{c}1.014^{* * *} \\
(9.15)\end{array}$ \\
\hline Price $_{t}$ & $\begin{array}{c}0.999 * * * \\
(-3.51)\end{array}$ & $\begin{array}{c}0.999^{* * *} \\
(-4.62)\end{array}$ \\
\hline $\mathrm{S} \& \mathrm{P} 500_{t}$ & $\begin{array}{c}0.928^{* * *} \\
(-4.19)\end{array}$ & $\begin{array}{c}0.930^{* *} \\
(-2.74)\end{array}$ \\
\hline Age $_{t}$ & $\begin{array}{l}1.000 \\
(0.94)\end{array}$ & $\begin{array}{c}0.997 \\
(-1.52)\end{array}$ \\
\hline $\operatorname{Stdev}_{t}$ & $\begin{array}{c}0.999 * * * \\
(-3.46)\end{array}$ & $\begin{array}{l}1.000 \\
(0.91)\end{array}$ \\
\hline $\operatorname{Return}_{t-1}$ & $\begin{array}{c}0.996^{* * *} \\
(-7.10)\end{array}$ & $\begin{array}{c}0.995 * * * \\
(-35.86)\end{array}$ \\
\hline $\mathrm{MTB}_{t}$ & $\begin{array}{c}0.967^{* * *} \\
(-2.79)\end{array}$ & $\begin{array}{c}0.969^{* * *} \\
(-8.96)\end{array}$ \\
\hline Dividend $_{t}$ & $\begin{array}{c}0.989 \\
(-1.03)\end{array}$ & $\begin{array}{c}0.899 * * * \\
(-11.95)\end{array}$ \\
\hline NumAnalyst $_{t}$ & $\begin{array}{c}1.001^{* *} \\
(1.97)\end{array}$ & $\begin{array}{c}1.008^{* * *} \\
(27.24)\end{array}$ \\
\hline Period Fixed Effects & Yes & Yes \\
\hline Fund-Stock Fixed Effects & No & Yes \\
\hline Observations & $4,768,145$ & $3,402,451$ \\
\hline
\end{tabular}




\section{Daily Fee}

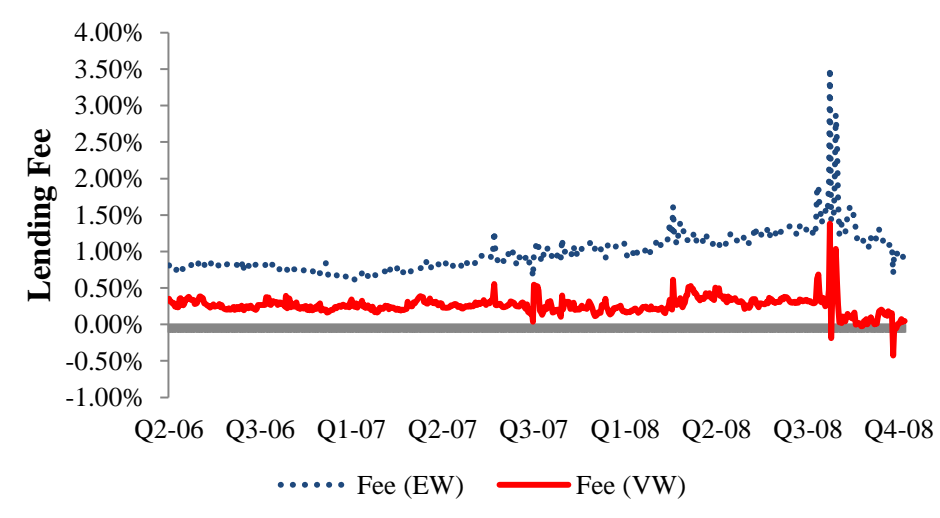

\section{Daily Loan Quantity}

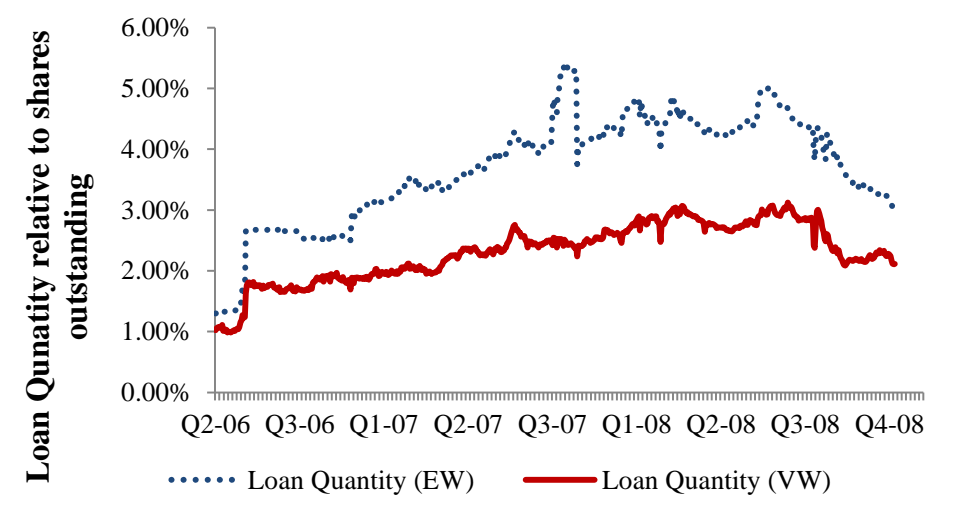

Figure 1

Daily Lending Fee and Loan Quantity

The top graph shows the daily equal (EW) and value weighted (VW) average lending fee for all stocks in the Data explorers data set for June 2006 to December 2008 and the bottom graph the daily loan quantity relative to shares outstanding. 
Figure 2

\section{Quarterly Institutional Ownership Changes of High Fee stocks}

Stocks with Fees $>=1 \%$

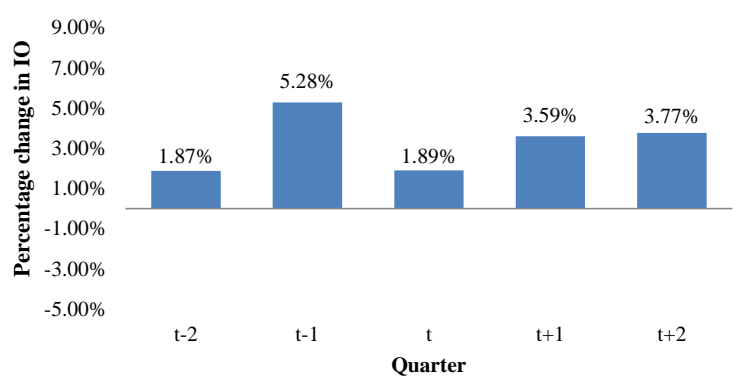

Stocks with Fees $>=1 \%$

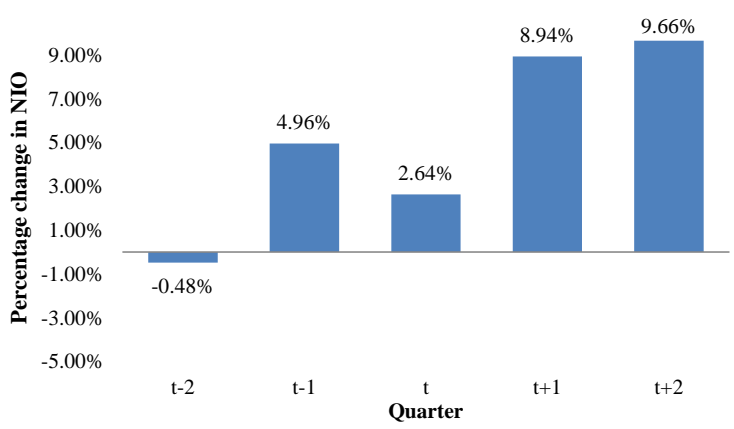

Stocks with Fees $<1 \%$
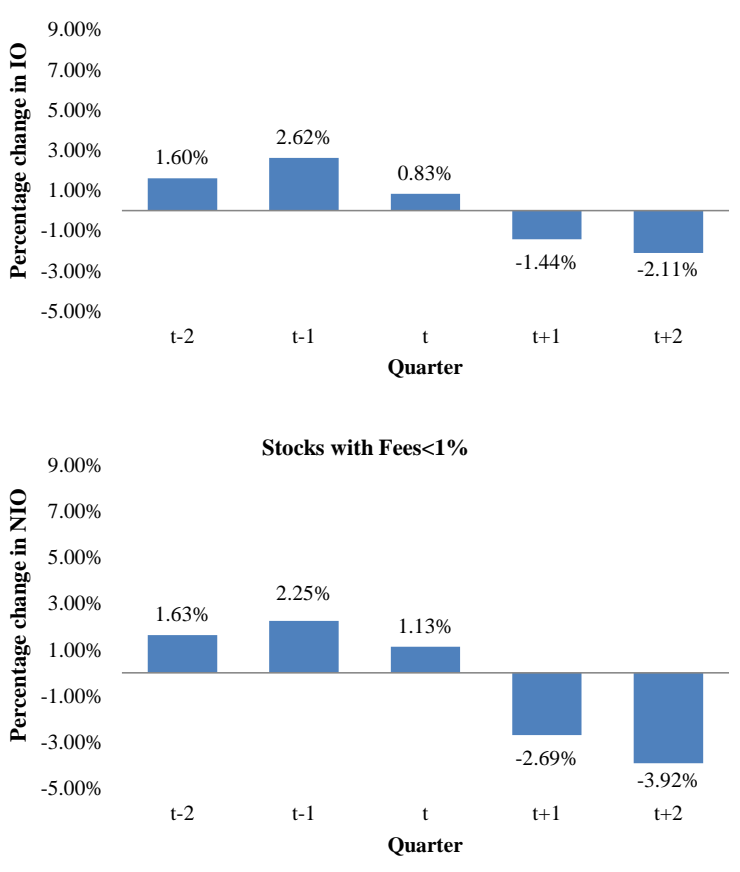

Top two panel graphs show the percentage change in institutional ownership for stocks with an annualized lending fee of $1 \%$ at time $t$ (right) and the remaining stocks with a lending fee below $1 \%$ at time $t$ (left), two quarters before and two quarters after the lending fee reaches the $1 \%$ threshold. The bottom two panel graphs show the percentage change in the number of institutional investors for stocks with an annualized lending fee of $1 \%$ at time $t$ (right) and the remaining stocks with a lending fee below $1 \%$ at time $t$ (left), two quarters before and two quarters after the lending fee reaches the $1 \%$ threshold. The details of data sources and variable definitions are in the appendix. 
Figure 3

Inventory and Loan Quantity of High Fee stocks
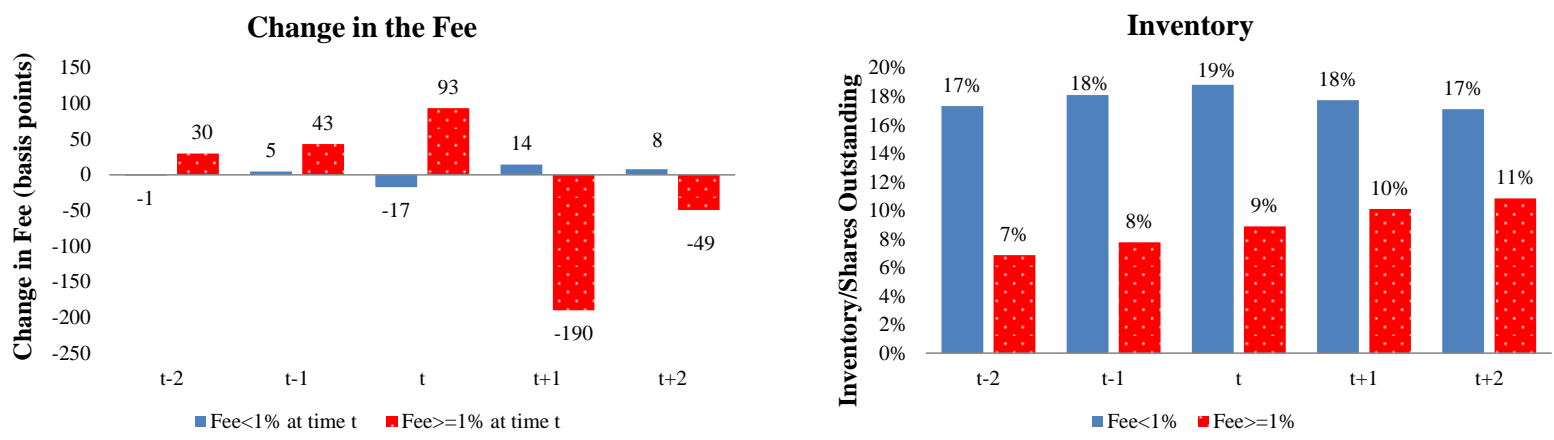

On Loan Quantity
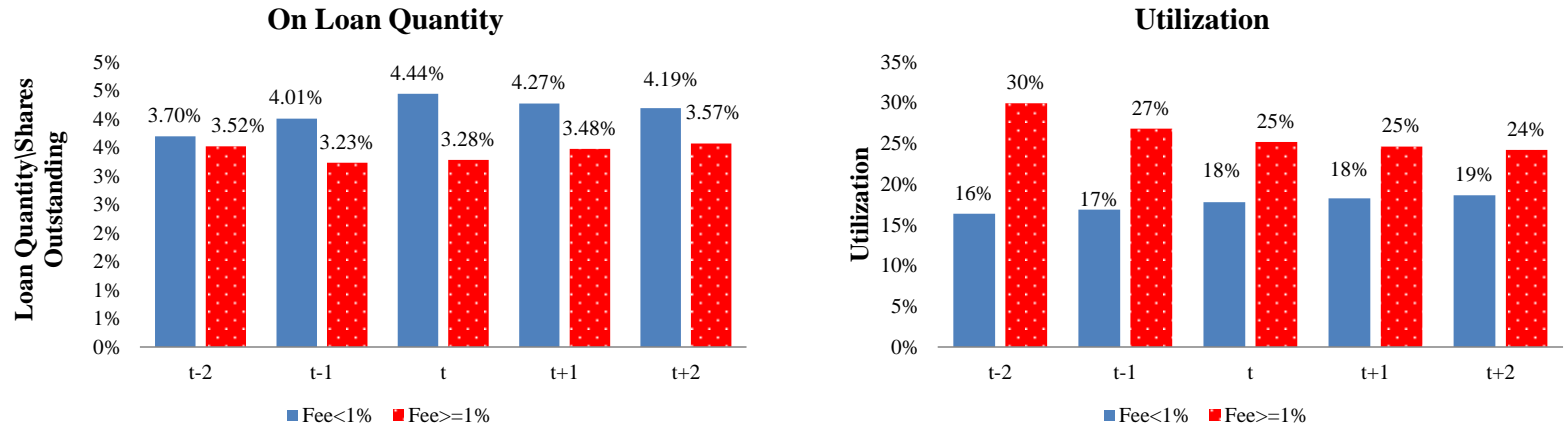

The change in fee in basis points, the percentage inventory, on loan quantities, and utilization of high $(f e e>=1 \%)$ and low fee $(f e e<1 \%)$ stocks, two quarters before and two quarters after the lending fee reaches the $1 \%$ threshold at time $t$. The details of data sources and variable definitions are in the appendix. 
Figure 4

Impulse Response of Institutional Trading to Fee
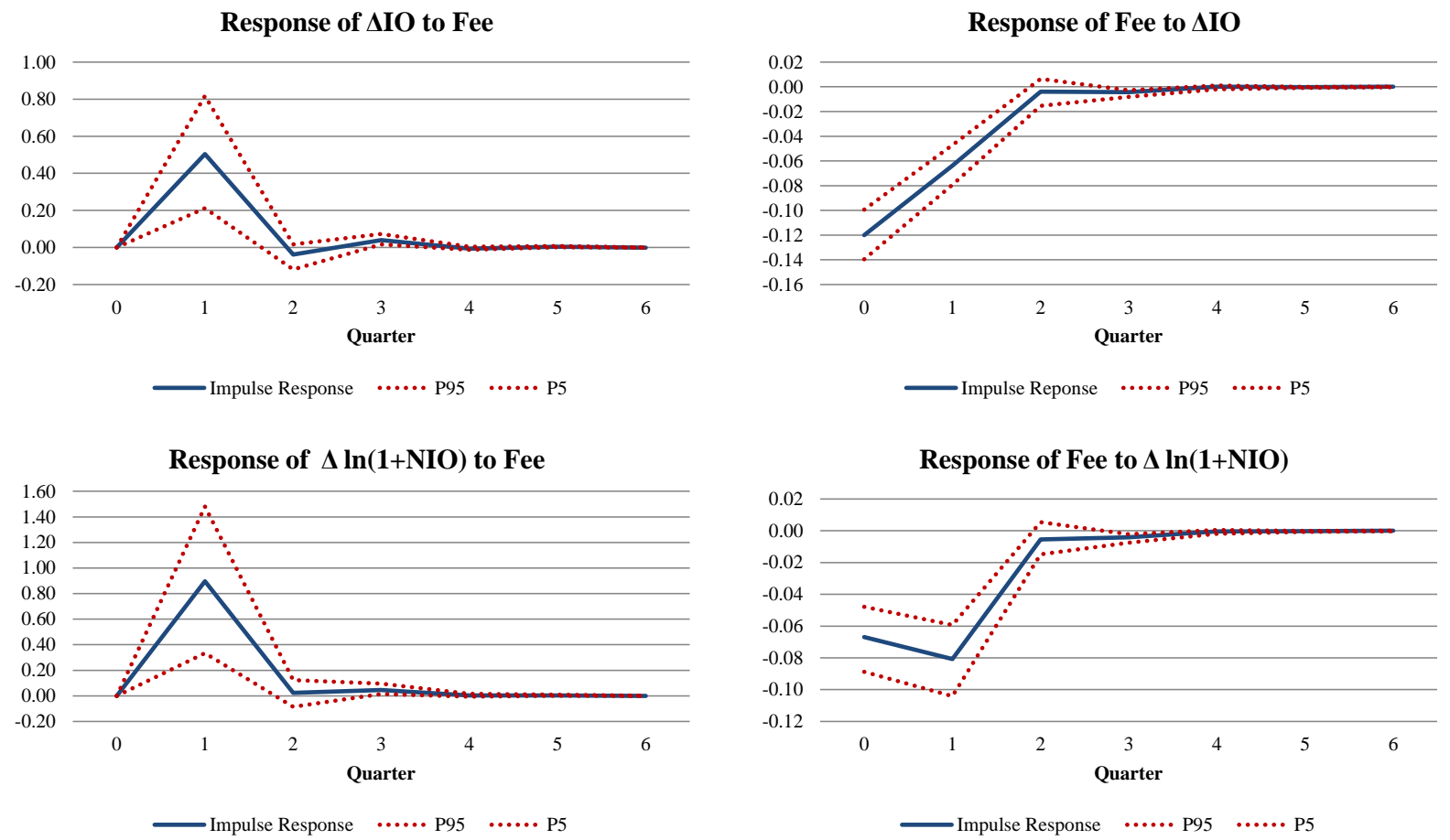

Impulse-response functions describing the reaction of the change in institutional ownership $(\Delta$ IO) to a one standard deviation innovation in fee (Top panel, left), and the reaction of fee (Top panel, right) to a one standard deviation innovation in the change in institutional ownership. Bottom panels impulse-response functions describe the reaction of the change in the number of institutional owners $(\Delta \ln (1+\mathrm{NIO})$ to a one standard deviation innovation in fee (Bottom panel, left), and the reaction of fee (Bottom panel, right) to a one standard deviation innovation in the change in the number of institutions. The impulse-response functions follow from a first-order VAR model specification and fund and period-specific fixed effects. The details of data sources and variable definitions are in the appendix. 


\section{Institutional Trade Rank and Change in \\ Lending Fee}

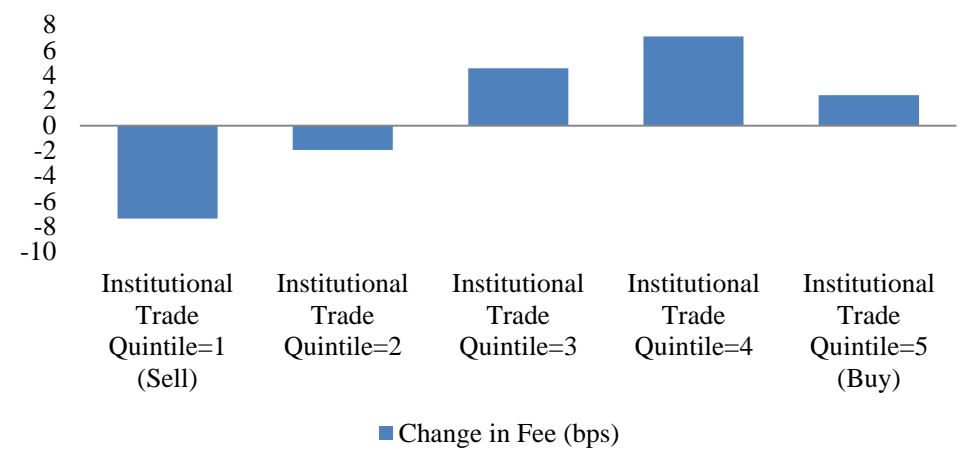

\section{Institutional Trade and Change in Lending Fee}

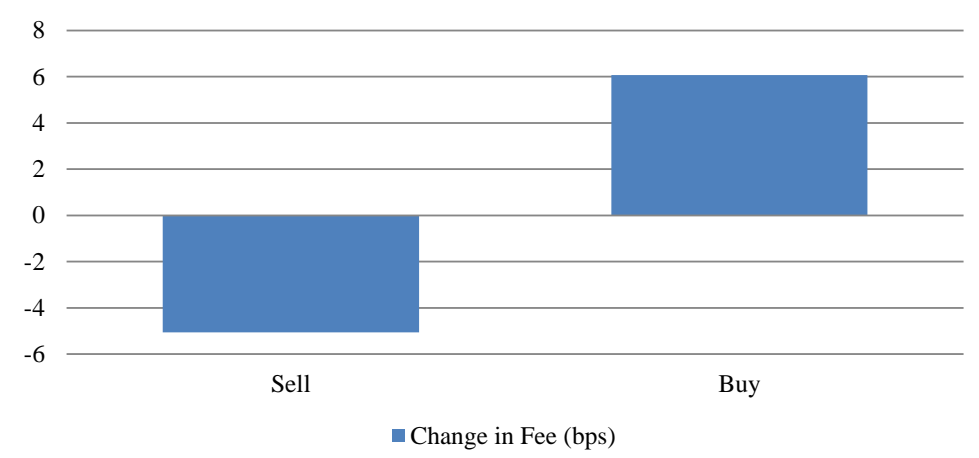

Figure 5

Trade and Fee rank

Each quarter a stock is ranked into 5 groups according to the change in institutional ownership. The top graph shows the average change in fee in basis points for stocks in each institutional trading quintile. The bottom graph shows the average change in fee in basis points for stocks that are bought and sold by institutional investors. A buy corresponds to an increase in institutional ownership and a sell a decrease. The details of data sources and variable definitions are in the appendix. 

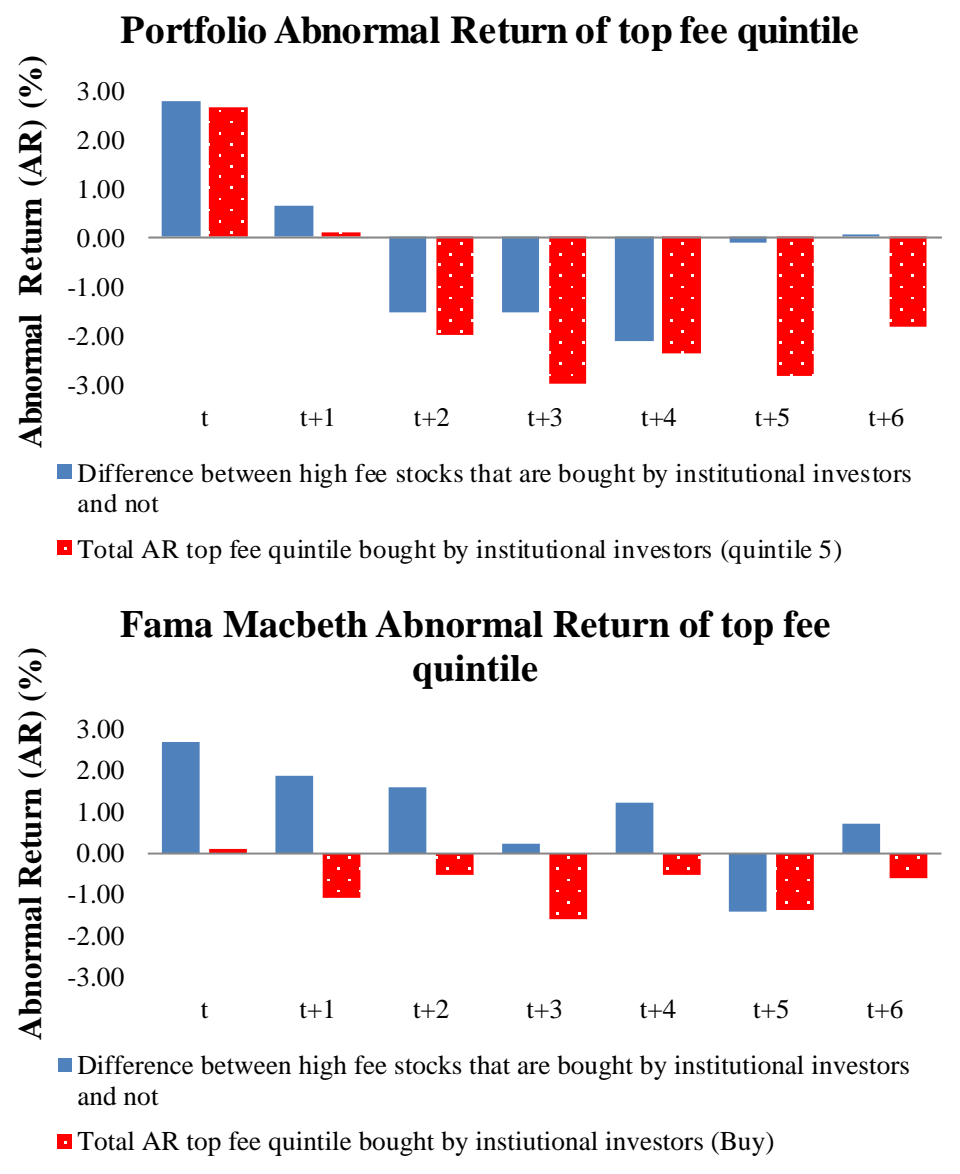

Figure 6

\begin{abstract}
Abnormal Return and Fee
The top graph (doted bar) shows the total annualized 4 factor abnormal return of the top fee quintile of stocks following a monthly calendar portfolio approach, up to 6 months after being ranked into the top fee quintile at time $t$.The graph also shows the difference between the premium on high minus low fee stocks for stocks that have been bought by institutional investors in the previous quarter versus stocks where the institutional holdings did not increase (solid bar). The graph below (doted bar) shows the total annualized 4 factor abnormal return of the top fee quintile of stocks after controlling for stock characteristics like size, MTB, age, standard deviation of returns, S\&P 500 indicator, bid-ask spread, turnover, number of analysts, and whether the stock pays dividends in a Fama Macbeth regression. The graph also shows the difference between the premium on high minus low fee stocks for stocks that have been bought by institutional investors in the previous quarter versus stocks where the institutional holdings did not increase (solid bar). The details of data sources and variable definitions are in the appendix.


Internet Appendix 


\section{Table A1}

\section{Trading Behavior and Short Squeeze}

Panel regression of the change in institutional ownership on fee increase and stock specific control variables, including short interest and loan quantity, year dummies and stock fixed effects. Results are reported in percentages. Year dummies and controls are not reported. Controls include size, MTB, age, standard deviation of returns, S\&P 500 indicator, bid-ask spread, turnover, price, past return, number of analysts and whether the stock pays dividends. Panel data are U.S. common equity stock from June 2006 to December 2008. Robust $t$-statistics in parentheses, ${ }^{* * *} p<0.01,{ }^{* *} p<0.05,{ }^{*} p<0.1$. The details of data sources and variable definitions are in the appendix.

\begin{tabular}{|c|c|c|c|c|c|c|}
\hline \multicolumn{7}{|c|}{ Panel A: Short Interest and Loan Quantity } \\
\hline & $(1)$ & $(2)$ & $(3)$ & $(4)$ & $(5)$ & $(6)$ \\
\hline & $\Delta \mathrm{IO}$ & $\Delta \ln (1+\mathrm{IO})$ & Odds Buy & $\Delta \mathrm{IO}$ & $\Delta \ln (1+\mathrm{IO})$ & Odds Buy \\
\hline \multirow[t]{2}{*}{ Fee increase } & $0.889^{* * *}$ & $1.365^{* * *}$ & $1.334^{* * *}$ & $0.830^{* * *}$ & $1.398^{* * *}$ & $1.316^{* * *}$ \\
\hline & $(8.169)$ & $(4.888)$ & $(10.354)$ & $(7.611)$ & $(4.957)$ & $(9.833)$ \\
\hline \multirow{2}{*}{ Short Interest } & -0.013 & $0.140 * *$ & 1.001 & & & \\
\hline & $(-0.751)$ & $(2.261)$ & $(0.187)$ & & & \\
\hline \multirow{2}{*}{ Loan Quantity } & & & & $0.212^{* * *}$ & -0.012 & $1.06^{* * *}$ \\
\hline & & & & $(9.132)$ & $(-0.261)$ & $(9.484)$ \\
\hline Observations & 30,642 & 30,642 & 29,681 & 30,642 & 30,642 & 29,681 \\
\hline$R^{2} /$ Pseudo $R^{2}$ & $15.17 \%$ & $21.24 \%$ & $3.89 \%$ & $15.48 \%$ & $21.19 \%$ & $4.20 \%$ \\
\hline \multicolumn{7}{|c|}{ Panel B: Subsample Small and Large Capitalization Stocks } \\
\hline \multirow{3}{*}{ Fee increase } & $(1)$ & $(2)$ & $(3)$ & $(4)$ & $(5)$ & $(6)$ \\
\hline & $0.582^{* * *}$ & $3.337 * * *$ & $1.209^{* * *}$ & $0.953 * * *$ & 0.160 & $1.287^{* * *}$ \\
\hline & $(3.389)$ & $(7.054)$ & $(3.854)$ & $(4.606)$ & $(0.387)$ & $(5.333)$ \\
\hline Subsample & Small Cap & Small Cap & Small Cap & Large Cap & Large Cap & Large Cap \\
\hline Observations & 11,678 & 11,678 & 11,037 & 9,628 & 9,628 & 9,151 \\
\hline$R^{2} /$ Pseudo $R^{2}$ & 0.174 & 0.233 & $3.39 \%$ & 0.160 & 0.241 & $2.38 \%$ \\
\hline Number of stocks & 1,787 & 1,787 & 1,479 & 1,424 & 1,424 & 1,175 \\
\hline
\end{tabular}


Table A2

\section{Risk adjusted Return and Short Squeeze}

Fama Macbeth regression explaining the Carhart (1997) 4-factor alpha with factor loadings estimated over the prior three years using monthly data and including the level of short interest and loan quantity (Panel A). The alphas are winsorized at $1 \%$ to minimize the impact of outliers. Panel B runs the same regression specification for the sample of large and small stocks. A stock is classified as small cap if the market capitalization is below $\$ 2$ billion, and large if the market capitalization is larger than $\$ 10$ billion. The reported results are in percentages. Stocks are classified as Special $_{t}$ if they belong to the highest fee quintile. $\widehat{\text { Special }}_{t}$ is an indicator variable that equals one if the stock is ranked as the highest predicted fee quintile. I predict the lending fee as a function of the occurrence of a failure-to-deliver and stock characteristics like size, MTB, age, standard deviation of returns, S\&P 500 indicator, bid-ask spread, turnover, price, number of analyst, past return and whether the stock pays dividends. The second prediction used for $\widehat{\text { Special }} 2_{t}$ includes proprietary information on utilization levels as reported by Data Explorers. Controls are not reported but include ln(Mcap), bid-ask, turnover, S\&P 500 (only for the subsample of large stocks), MTB, number of analyst, dividend. Robust $t$-statistics in parentheses, ${ }^{* * *} p<0.01,{ }^{* *} p<0.05,{ }^{*} p<0.1$. The details of data sources and remaining variable definitions are in the appendix.

\begin{tabular}{|c|c|c|c|c|c|c|}
\hline \multicolumn{7}{|c|}{ Panel A: Short Interest and Loan Quantity } \\
\hline & (1) & $(2)$ & $(3)$ & $(4)$ & $(5)$ & $(6)$ \\
\hline Buy $_{t-1}$ & -0.024 & 0.015 & 0.022 & -0.016 & 0.021 & 0.029 \\
\hline & $(-0.59)$ & $(0.46)$ & $(0.74)$ & $(-0.39)$ & $(0.64)$ & $(0.97)$ \\
\hline Special $_{t}$ & $\begin{array}{c}-0.238^{* * *} \\
(-2.87)\end{array}$ & & & $\begin{array}{c}-0.250 * * * \\
(-2.99)\end{array}$ & & \\
\hline $\operatorname{Special}_{t} * \mathrm{Buy}_{t-1}$ & $\begin{array}{c}0.366^{* *} \\
(2.51)\end{array}$ & & & $\begin{array}{c}0.366^{* *} \\
(2.46)\end{array}$ & & \\
\hline$\widehat{\text { Special }_{t}}$ & & $\begin{array}{l}-0.067 \\
(-0.73)\end{array}$ & & & $\begin{array}{l}-0.057 \\
(-0.62)\end{array}$ & \\
\hline$\widehat{S p e c i a l}_{t} * \mathrm{Buy}_{t-1}$ & & $\begin{array}{c}0.196 * * \\
(2.12)\end{array}$ & & & $\begin{array}{c}0.204^{* *} \\
(2.21)\end{array}$ & \\
\hline$\widehat{\text { Special }}_{t} 2$ & & & $\begin{array}{c}-0.200^{* *} \\
(-2.45)\end{array}$ & & & $\begin{array}{c}-0.199^{* *} \\
(-2.43)\end{array}$ \\
\hline $\operatorname{Special}_{t} 2 * \mathrm{Buy}_{t-1}$ & & & $\begin{array}{l}0.174 \\
(1.47)\end{array}$ & & & $\begin{array}{l}0.173 \\
(1.47)\end{array}$ \\
\hline Short Interest & $\begin{array}{c}-0.023^{*} \\
(-2.03)\end{array}$ & $\begin{array}{c}-0.023^{*} \\
(-2.03)\end{array}$ & $\begin{array}{c}-0.022^{*} \\
(-2.06)\end{array}$ & & & \\
\hline Loan Quantity & & & & $\begin{array}{l}-2.349 \\
(-1.71)\end{array}$ & $\begin{array}{c}-2.370^{*} \\
(-1.78)\end{array}$ & $\begin{array}{l}-2.085 \\
(-1.60)\end{array}$ \\
\hline Controls & Yes & Yes & Yes & Yes & Yes & Yes \\
\hline Observations & 62,010 & 62,010 & 62,010 & 62,010 & 62,010 & 62,010 \\
\hline$R^{2}$ & $4.20 \%$ & $4.18 \%$ & $4.19 \%$ & $4.19 \%$ & $4.18 \%$ & $4.17 \%$ \\
\hline
\end{tabular}


Continued from Previous Page

\begin{tabular}{|c|c|c|c|c|c|c|}
\hline \multicolumn{7}{|c|}{ Panel B: Subsample Small and Large Capitalization Stocks } \\
\hline \multirow{3}{*}{$\operatorname{Buy}_{t-1}$} & $(1)$ & $(2)$ & $(3)$ & $(4)$ & $(5)$ & $(6)$ \\
\hline & 0.049 & $0.154^{*}$ & $0.138^{* *}$ & -0.080 & $-0.112^{* *}$ & $-0.097^{*}$ \\
\hline & $(0.50)$ & $(1.88)$ & $(2.16)$ & $(-1.52)$ & $(-2.21)$ & $(-1.79)$ \\
\hline \multirow[t]{2}{*}{ Special $_{t}$} & $-0.444^{* * *}$ & & & -0.213 & & \\
\hline & $(-4.06)$ & & & $(-1.17)$ & & \\
\hline \multirow{2}{*}{ Special $_{t}^{*}$ Buy $_{t-1}$} & 0.367 & & & $0.500^{* *}$ & & \\
\hline & $(1.44)$ & & & $(2.45)$ & & \\
\hline \multirow[t]{2}{*}{$\widehat{\text { Special }} l_{t}$} & & -0.198 & & & $-0.447^{*}$ & \\
\hline & & $(-1.08)$ & & & $(-1.94)$ & \\
\hline \multirow[t]{2}{*}{ Special $_{t} *$ Buy $_{t-1}$} & & 0.137 & & & $0.370 * * *$ & \\
\hline & & $(0.64)$ & & & $(3.17)$ & \\
\hline \multirow[t]{2}{*}{$\widehat{\text { Special }}_{t} 2$} & & & $-0.608 * * *$ & & & $-0.273^{*}$ \\
\hline & & & $(-4.04)$ & & & $(-2.05)$ \\
\hline \multirow{2}{*}{\multicolumn{2}{|c|}{$\operatorname{Special}_{t} 2 * \mathrm{Buy}_{t-1}$}} & & $0.284^{*}$ & & & $0.377^{*}$ \\
\hline & & & $(1.82)$ & & & $(1.96)$ \\
\hline \multirow[t]{2}{*}{ Subsample } & Small & Small & Small & Large & Large & Large \\
\hline & Cap & Cap & Cap & Cap & Cap & Cap \\
\hline Observations & 21,746 & 21,746 & 21,746 & 22,098 & 22,098 & 22,098 \\
\hline$R^{2}$ & $3.25 \%$ & $3.40 \%$ & $3.45 \%$ & $6.25 \%$ & $6.29 \%$ & $6.51 \%$ \\
\hline
\end{tabular}


Figure A1

Impulse Response of Institutional Trading to Fee Increase/High Fee
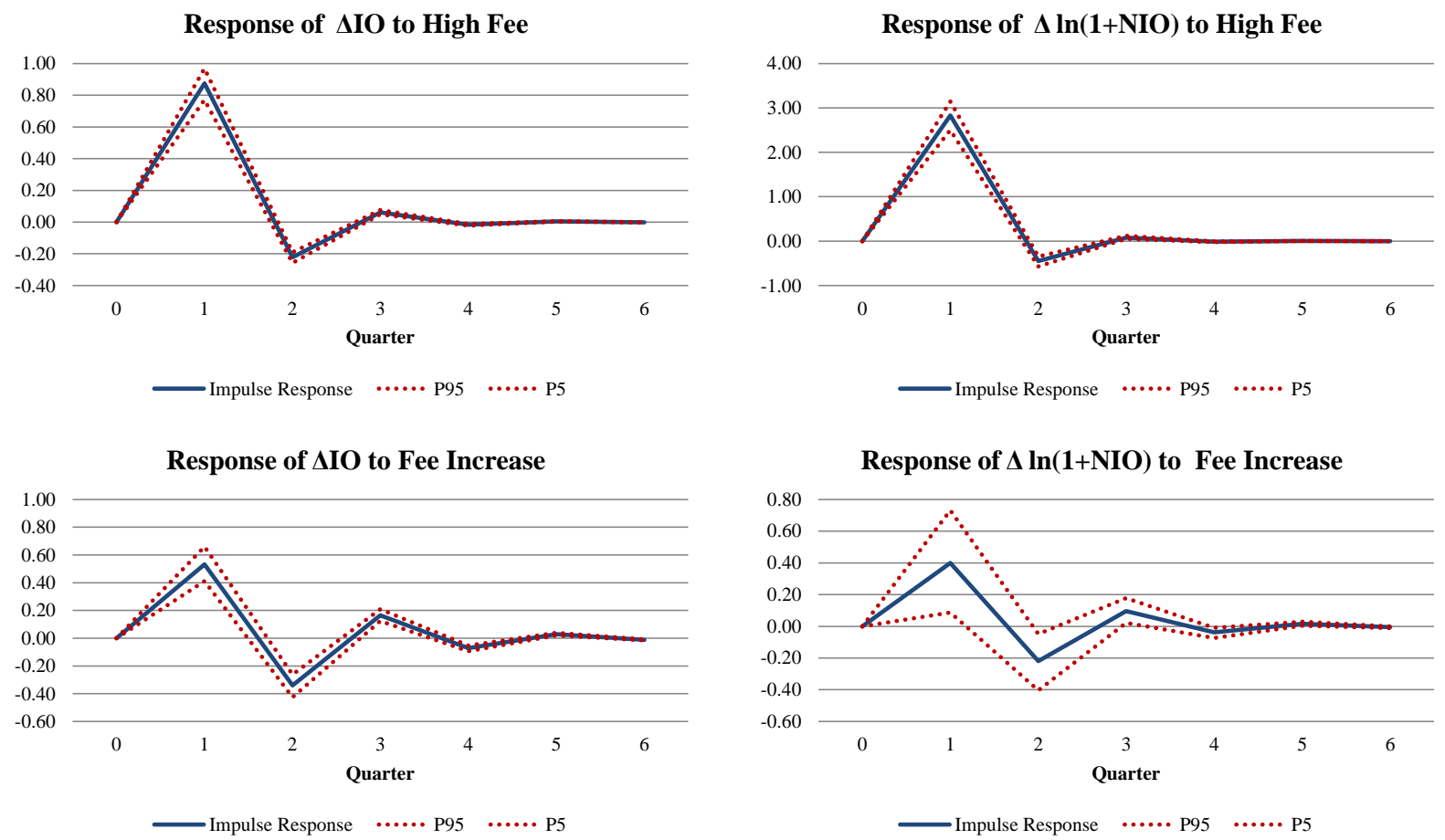

Impulse-response functions describing the reaction of the change in institutional ownership ( $\Delta$ IO) to a one standard deviation innovation in fee (Top panel, left), and the reaction of fee (Top panel, right) to a one standard deviation innovation in the change in institutional ownership. Bottom panels impulse-response functions describe the reaction of the change in the number of institutional owners $(\Delta \ln (1+\mathrm{NIO})$ to a one standard deviation innovation in fee (Bottom panel, left), and the reaction of fee (Bottom panel, right) to a one standard deviation innovation in the change in the number of institutions. The impulse-response functions follow from a first-order VAR model specification and fund and period-specific fixed effects. The details of data sources and variable definitions are in the appendix. 